\title{
The Bushmanland Group supracrustal succession, Aggeneys, Bushmanland, South Africa: Provenance, age of deposition and metamorphism
}

\author{
Russell Bailie \\ Department of Geological Sciences, University of Cape Town, Private Bag, Rondebosch, 7700, South Africa \\ Present address: Paleoproterozoic Mineralisation Research Group, Dept. of Geology, University of Johannesburg, \\ P.O. Box 524, Auckland Park, Johannesburg, 2006, South Africa \\ e-mail: russellb@postgrad.uj.ac.za

\section{Richard Armstrong} \\ Research School of Earth Sciences, The Australian National University, Canberra, 0200, A.C.T., Australia \\ e-mail: richard.armstrong@anu.edu.au \\ David Reid \\ Department of Geological Sciences, University of Cape Town, Private Bag, Rondebosch, 7700, South Africa \\ e-mail: dlr@geology.uct.ac.za
}

(c) 2007 March Geological Society of South Africa

\begin{abstract}
The central portion of the structurally complex and poly-metamorphosed Namaqua Province of western South Africa is underlain by a series of pelitic and psammitic metasediments, termed the Bushmanland Group, which is host to world class Broken Hill-type $\mathrm{Pb}-\mathrm{Zn}$-Cu-Ag deposits at Aggeneys. Geochemical, U-Pb SHRIMP zircon geochronology and Sm-Nd isotopic determinations of the metasediments at Aggeneys were undertaken to determine the age and nature of the provenance, as well as to confine the age of deposition of the Bushmanland Group in this area.

The metasediments were derived from moderately-weathered granodiorites to granites, or their volcanic equivalents, with $\sim 2.65$ to $\sim 2.25 \mathrm{Ga}$ Sm-Nd $\mathrm{T}_{\mathrm{DM}}$ model ages. Mixed sources are likely from the geochemical signatures of the metasediments as well as the varied detrital zircon ages, with two main age groupings present of $\sim 2.12$ to $\sim 1.97 \mathrm{Ga}$ and $\sim 1.88 \mathrm{Ga}$ to $\sim 1.64 \mathrm{Ga}$. The upper part of the succession has a narrower compositional range and was derived from a more mafic provenance than the basal portion. The provenance is likely to have been a combination of $\sim 1.8 \mathrm{Ga}$ Gladkop Suite granitic gneisses found to the west and the $\sim 2.1$ to $\sim 1.9 \mathrm{Ga}$ intrusive and volcanosedimentary rocks of the Richtersveld Subprovince to the northwest. The metasediments were deposited in a passive margin setting and underwent extensive reworking in addition to recycling.

The time of deposition of the Bushmanland Group is constrained between the age of the youngest detrital zircon ( 1.64 Ga) and the onset of the regionally extensive Kibaran Orogeny at $\sim 1.2 \mathrm{Ga}$. Metamorphic overgrowths and rims on detrital zircons record two distinct events, the $\sim 1.21$ to $\sim 1.18$ Ga Kibaran Orogeny, characterised by extensive granitic magmatism, peak $D_{2}$ deformation and peak upper amphibolite facies grade $M_{2}$ metamorphism, and the more ubiquitous $\sim 1.04$ to $\sim 1.01$ Ga Namaquan Orogeny characterised by weaker $M_{3}$ metamorphism.
\end{abstract}

\section{Introduction}

The Broken Hill-type Pb-Zn-Cu-Ag deposits at Aggeneys, South Africa are world-class examples of an important mineralisation type (Beeson, 1990; Walters, 1996). The Aggeneys deposits are situated in the central region of the Proterozoic Namaqua Sector of the Namaqua-Natal Belt, a belt of highly deformed mediumto high-grade metamorphic rocks to the south and west of the Archean Kaapvaal Craton of South Africa (Figure 1). The structural complexity of the region and the high grade of metamorphism has led to complications in correlating rocks, particularly those of the supracrustal successions, from one area to another (Joubert, 1986; Moore, 1989) and has led to complicated tectonic models for the area (summarized in Joubert, 1986). The importance in determining the tectonic evolution of the area lies not only in its economic potential as hosts of Broken Hill-type deposits, but also in its role in the amalgamation of the southern African continental crust during the construction of the Rodinian supercontinent at $\sim 1.2$ to $\sim 1.0 \mathrm{Ga}$ (Thomas et al., 1993a, 1994).

Numerous geochronological studies have been undertaken on the Cu-rich Okiep District of the western Namaqua Province (Clifford et al., 1975; 1981; 1995; 2004; Robb et al., 1999; Figure 1), but only a few (e.g. Armstrong et al., 1988) have been done on the economically significant Bushmanland Group metasedimentary succession around Aggeneys, with previous age determinations (Reid et al., 1987; 1997a) having focused on whole rock radiogenic isotope systematics to postulate the age of deposition of the Bushmanland Group. Furthermore, there has been protracted debate as to the provenance, basement and source of base metals to the supracrustal succession (Duncan et al., 1984; 1985; Watkeys, 1986; Watkeys et al., 1988a; b; Moore, 1989, Moore et al., 1990; Lipson, 1990; Reid et al., 1997a; b). These arguments have 


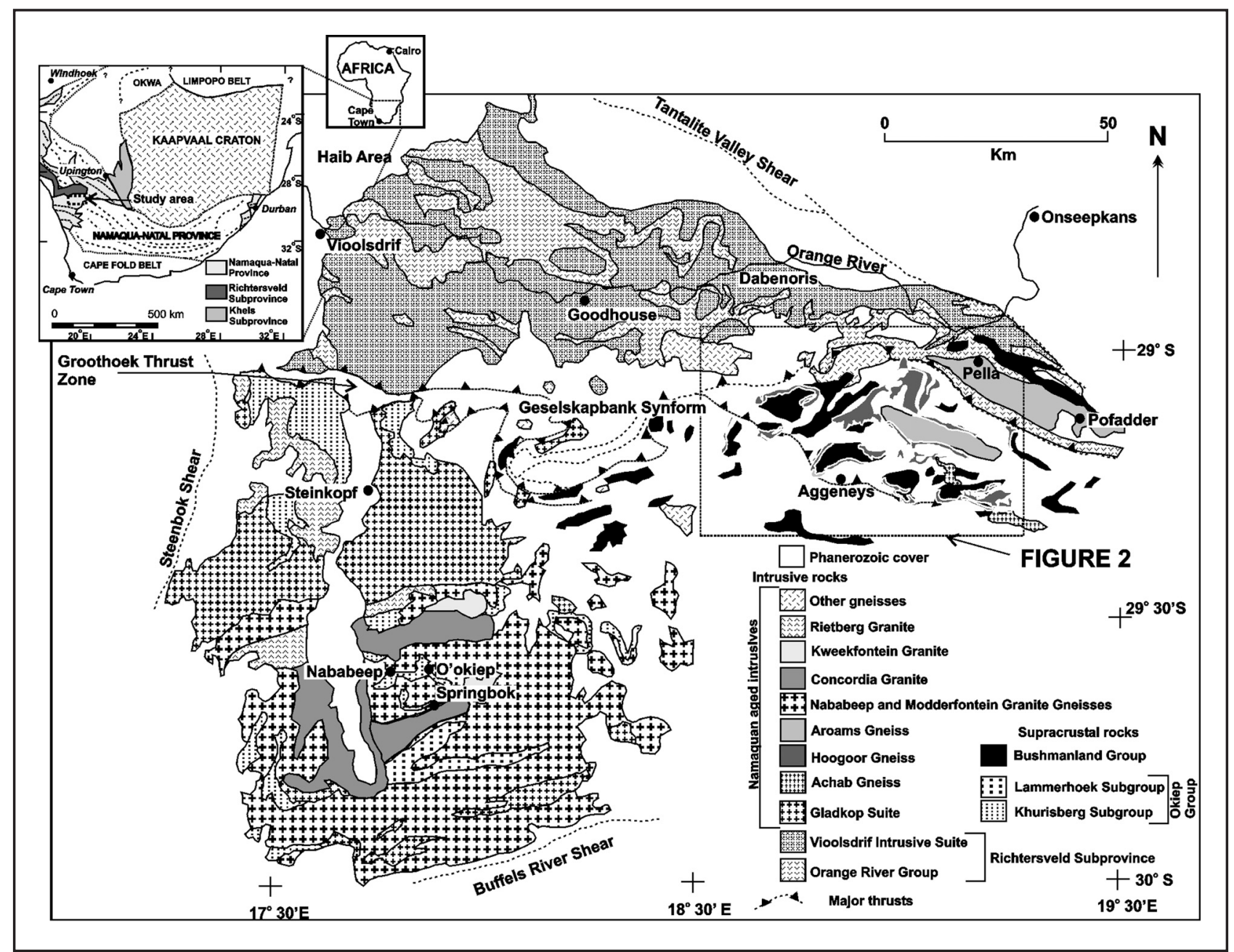

Figure 1. Location of the study area in South Africa (modified after Van Aswegen et al., 1987). The upper left inset shows the tectonic setting of the Namaqua-Natal Province (after Thomas et al., 1993a).

suggested that the present-day basement, a series of granitic gneisses termed the Achab and Hoogoor Gneisses, are older than the Bushmanland Group and acted as the basement and provenance to the metasediments and source of the base metal mineralisation. These arguments have been made based on the geochemical and isotopic characteristics of the gneisses despite the highly deformed nature of both the gneisses and the metasediments and the structural contact between the two which makes the relationship unclear (Watkeys, 1986). Lipson (1990) argued for a Paleoproterozoic provenance to the northwest of the Bushmanland Group with its deposition on an unknown basement.

In light of this debate, it was decided to re-examine the geochemistry and geochronology of the Bushmanland Group metasediments. This paper examines the geochemistry of the metasediments using the data of Lipson (1990), and incorporates new trace element and Sm-Nd isotope data in order to assess the provenance and tectonic setting of the Bushmanland Group in the Aggeneys area. In addition, single zircon geochronological analyses on detrital zircons within the Bushmanland Group were obtained to give a better estimate of the age of deposition of the metasediments as well as an indication of the age of the source region.

\section{Regional Geological Setting}

The economically important deposits, near the town of Aggeneys within the Northern Cape Province of South Africa, $\sim 110 \mathrm{~km}$ to the northeast of the town of Springbok and $\sim 80 \mathrm{~km}$ to the west of Pofadder (Figure 1), are the biggest source of lead and zinc metal in the country (Ryan et al., 1986). They are known as, from west to east, Black Mountain, Broken Hill, Big Syncline and Gamsberg (Figure 2). The deposits become progressively zinc-rich and lead-poor from the Cu-rich Black Mountain deposit in the west (Ryan et al., 1986) to the large tonnage, low-grade Zn-rich Gamsberg deposit in the east (Rozendaal, 1986). The prominent inselbergs and ranges of hills which characterise the arid landscape of the area are formed by the metavolcanicmetasedimentary units of the Bushmanland Group that usually occur as major, often overturned, synformal infolds in the associated granitic gneisses (Joubert, 1974). Apart from geochemical characteristics the metasedimentary nature of the metapelites and metaquartzites is confirmed by the presence of heavy 


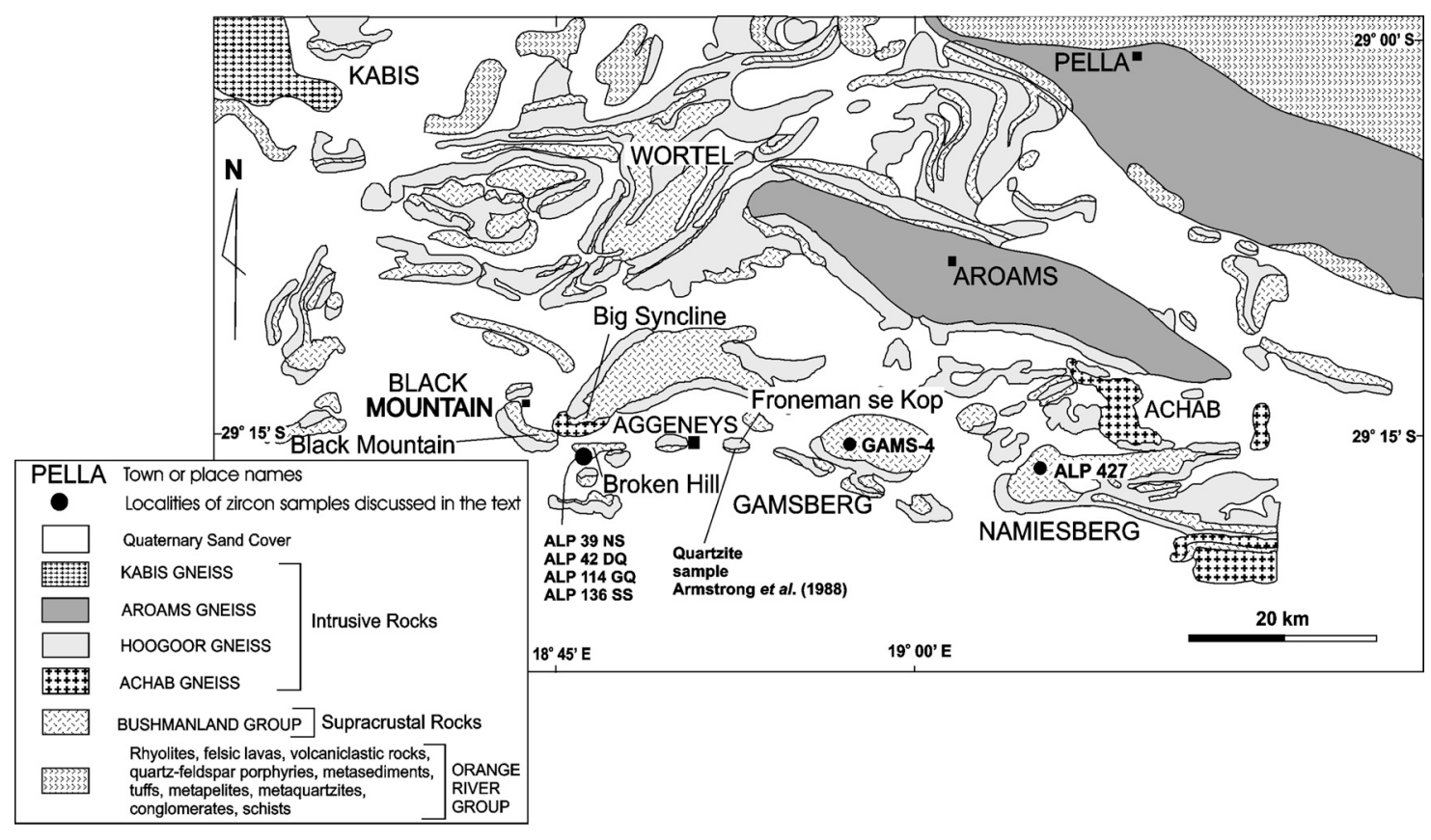

Figure 2. Simplified geological map of the Bushmanland area around Aggeneys and Gamsberg showing the various inselbergs and the distribution of the various granitic gneisses and the Bushmanland Group supracrustal succession (after Reid et al., 1997a). The localities of the samples for the geochronological study are shown.

mineral layers and the presence of other sedimentary features, such as cross bedding within the metaquartzite units (Lipson et al., 1986).

The deposits occur in the northwestern portion of the highly deformed and metamorphosed NamaquaNatal Belt of southern Africa (Figure 1), an area of reworked and juvenile $\sim 1.2$ to 1.0 Ga crust deposited on, or intruded into older $\sim 2.0$ Ga Eburnian crust represented by the Richtersveld Subprovince to the northwest of Aggeneys (Thomas et al., 1993a). Mediumto high-grade metamorphism accompanied polyphase deformation of the original sedimentary and volcanic rocks (Thomas et al., 1993a) due to collision or accretion of the Belt with the Kaapvaal Craton at $\sim 1.2$ to $\sim 1.1 \mathrm{Ga}$ (Jacobs et al., 1993).

Previous radiometric dating on the rocks of the Namaqua Sector (Nicolaysen and Burger, 1965; Clifford et al., 1975; 1981; 1995; 2004; Reid, 1979a; Barton, 1983; Reid et al., 1997a; Robb et al., 1999; Clifford et al., 2004) have revealed a pattern of $\sim 1.21$ to 0.95 Ga magmatism, tectonism and metamorphism (Thomas et al., 1993a; 1994) associated with a major period of continental growth and accretion and the amalgamation of the Rodinian supercontinent (Hoffman, 1991). Within this $\sim 1.21$ to $\sim 0.95$ Ga period two major tectono-magmatic episodes are recognised, namely one at $\sim 1.21$ to $\sim 1.17$ $\mathrm{Ga}$, and a second at $\sim 1.06$ to $\sim 1.03 \mathrm{Ga}$, termed the Kibaran and Namaquan orogenies respectively (Robb et al., 1999).

The meta-volcanosedimentary supracrustal succession throughout the Bushmanland Subprovince is represented by the Okiep and Bushmanland Groups which occur within the Okiep and Aggeneys Districts respectively. These compositionally variable sequences comprise chemogenic units, meta-arenites and minor intercalated volcanic rocks. The Bushmanland Group includes ferruginous quartzite, shale, calc-silicate assemblages and amphibolite along with the associated $\mathrm{Pb}-\mathrm{Zn}$-Cu-Ag massive sulphide mineralisation at Aggeneys and Gamsberg (Robb et al., 1999). The Okiep Group includes quartzite, cordierite-bearing parageneses, granulites and calc-silicate rocks (Clifford et al., 2004). These metasediments and metavolcanics are intruded by, and/or rest on voluminous granitic gneisses predominantly represented by the Little Namaqualand Suite (Blignault et al., 1983) that obliterated any present-day traces of a pre-existing basement. The metasediments are thus preserved as rafts surrounded and intruded by voluminous granitic gneisses.

The age of Bushmanland Group deposition had previously been constrained between $\sim 2.0$ to $\sim 1.65 \mathrm{Ga}$ (Reid et al., 1987; 1997a). Single zircon SHRIMP U-Pb ages of $\sim 2.0$ to $\sim 1.8 \mathrm{Ga}$ were obtained from detrital zircons (Armstrong et al., 1988) in a heavy mineral layer in a quartzite at Froneman se Kop at Aggeneys (Lipson et al., 1986; Figure 2). Reid et al. (1987) obtained a SmNd isochron age of $1649 \pm 90$ Ma from the Koeris Formation amphibolite overlying the Bushmanland Group. As the volcanic rocks of the Koeris Formation constitute the youngest geological succession in the area (Geological Staff Black Mountain, 1996; McClung et al., 2002) (Table 1), their age is thought to provide a good estimate for the upper age of deposition of the 
Bushmanland Group. In addition, single zircon $\mathrm{U}-\mathrm{Pb}$ SHRIMP ages of $2.0 \mathrm{Ga}$ were obtained from the Achab Gneiss (Armstrong et al., 1988), which had been interpreted as the basement to the Bushmanland Group (Moore, 1977; Watkeys, 1986).

The Aggeneys District has been subjected to three major metamorphic and five deformational events (Lipson, 1978; Stedman, 1980; Ryan et al., 1986; Colliston et al., 1989; Lipson, 1990; Hoffmann, 1993; Geological Staff Black Mountain, 1996; Colliston and Schoch, 2003). Peak prograde metamorphism $\left(M_{2}\right)$, which attained upper amphibolite facies grade metamorphic conditions of $690^{\circ} \mathrm{C}$ at $4 \mathrm{kbar}$ (Lipson, 1978; Rozendaal, 1978; Waters, 1986; 1987; 1989; Hoffmann, 1993; Willner, 1995), was related to peak $D_{2}$ deformation represented by recumbent isoclinal north-east plunging folds $\left(F_{2}\right)$ (Ryan et al., 1986), and associated thrusting, that dominate the structural pattern of the metasediments and is responsible for tectonic duplication. The third phase of deformation $\left(D_{3}\right)$, which accompanied $M_{3}$ metamorphism, resulted in large-scale, open, asymmetric $\left(F_{3}\right)$ folds striking east-north-east (Ryan et al. 1986). The fourth phase of deformation $\left(D_{4}\right)$ is represented by northerly-trending monoclinal folds and faults oriented northerly to northwesterly (Stedman, 1980). Northeasterly-trending strike-slip faults and shear zones characterise $D_{5}$ deformation (Ryan et al., 1986; Colliston and Schoch, 2003).

The Namaqua Province is a HT/LP province with pressures not exceeding $6 \mathrm{kbar}$ (Willner, 1995). Willner (1995) suggested near isobaric heating prior to peak temperature conditions. $D_{2}$ deformation occurred due to thrusting and crustal stacking (Joubert, 1974; Moore, 1977; Watkeys, 1986; Van Aswegen et al., 1987). The retrograde PT-path indicates a definite pressure decrease with lower temperatures with the later metamorphic event $\left(M_{3}\right)$ determined to be 550 to $600^{\circ} \mathrm{C}$ at 2.5 kbar (Willner, 1995). The rocks of central Bushmanland thus show a clockwise P-T- $t$ path as opposed to the anti-clockwise P-T- $t$ path determined for the granulite facies grade rocks to the west in the Okiep District (Waters, 1989; Willner, 1995).

\section{Stratigraphic Nomenclature}

The complex structural pattern of the Aggeneys District has led to difficulties in correlating stratigraphic units from area to area. Some workers (Colliston et al., 1986; 1989; 1991; Praekelt and Schoch, 1997; Praekelt et al., 1997; Colliston and Schoch, 1998) have argued that correlation between areas is not feasible and have devised a plethora of stratigraphic names in different areas where different successions have been mapped. Other workers (Moore, 1989; Lipson, 1990), have, however, argued for a simpler, $1000 \mathrm{~m}$ thick succession that has undergone extensive tectonic duplication and stacking due to thrusting and deformation. Consequently, different workers have applied different stratigraphic columns and stratigraphic names in different areas (Table 1).
The Bushmanland Group developed locally around the $\mathrm{Pb}-\mathrm{Zn}-\mathrm{Cu}-\mathrm{Ag}$ mineralisation in the Aggeneys District consists predominantly of aluminous schists interspersed with lesser quartzite, calc-silicate assemblages, amphibolites and iron formations. The supracrustal succession structurally overlies a series of granitic gneisses that generally include grey augen gneiss overlain by pink gneisses of the Hoogoor Suite. Regionally, the Bushmanland Group is subdivided into the Wortel and Kouboom Subgroups and capped by the Koeris Formation (McClung et al., 2002) (Table 1). Previously the Bushmanland Group had been subdivided into a number of formations comprising various units or members (Rozendaal, 1975; Lipson, 1978; 1990) based on local mapping. McClung et al. (2002) argued that, from regional mapping, the Bushmanland Group should be subdivided into two major subgroups comprising a number of formations. The Wortel Subgroup comprises a basal aluminous metapelitic schist, termed the Namies Schist Formation, overlain by a clean white quartzite and pelitic schist, termed the Pella Quartzite and Pelitic Schist Formations respectively. McClung et al. (2002) recognised a regional unconformity above the Pelitic Schist Formation that separated the Wortel Subgroup from the overlying Kouboom Subgroup. The base of the Kouboom Subgroup is a dark quartzite termed the Broken Hill Quartzite Formation. Locally, such as at Gamsberg (Rozendaal, 1975) and at Aggeneys (Lipson, 1978; 1990; Ryan et al., 1986), the two quartzite horizons with intervening pelitic schist have been included into one formation, variably given different names by different workers (Table 1) and the unconformity below the dark quartzite not identified. Above the Broken Hill Quartzite Formation at the base of the Kouboom Subgroup are a series of pelitic schists, iron formations and calc-silicates that host the massive sulphide $\mathrm{Pb}-\mathrm{Zn}-\mathrm{Cu}-\mathrm{Ag}$ mineralisation. This has been termed the Gams Formation regionally, but at Aggeneys has been termed the Aggeneys Ore Formation by Ryan et al. (1986) and further subdivided into the Ore Schist and Shaft Schist Formations by Lipson (1978; 1990), each comprising a number of different lithological units (Table 1). The Gams Formation of the Kouboom Subgroup is unconformably overlain by a series of quartz-sericite schists, conglomerates, amphibolites and leucocratic gneisses termed the Nousees Mafic Gneiss by Rozendaal (1975) at Gamsberg, but termed the Koeris Formation regionally by McClung et al. (2002). While this formation has been included into the Bushmanland Group in the past (Table 1), its sharply erosive unconformable contact, which can cut down to the Namies Schist level in the underlying supracrustal succession, suggests that it is significantly younger and should not be included in the Bushmanland Group (McClung et al., 2002).

As this study uses samples from the Broken Hill Mine at Aggeneys the local stratigraphic subdivision of the Bushmanland Group by Lipson (1990) at Aggeneys will be used, as this subdivides the succession into smaller 
Table 1. Selected stratigraphic columns for the Bushmanland Group on a regional scale (SACS, 1980; McClung et. al., 2002), and in the Aggeneys-Gamberg District (Rozendaal, 1975, Lipson, 1978, 1990; Ryan et.al., 1986).
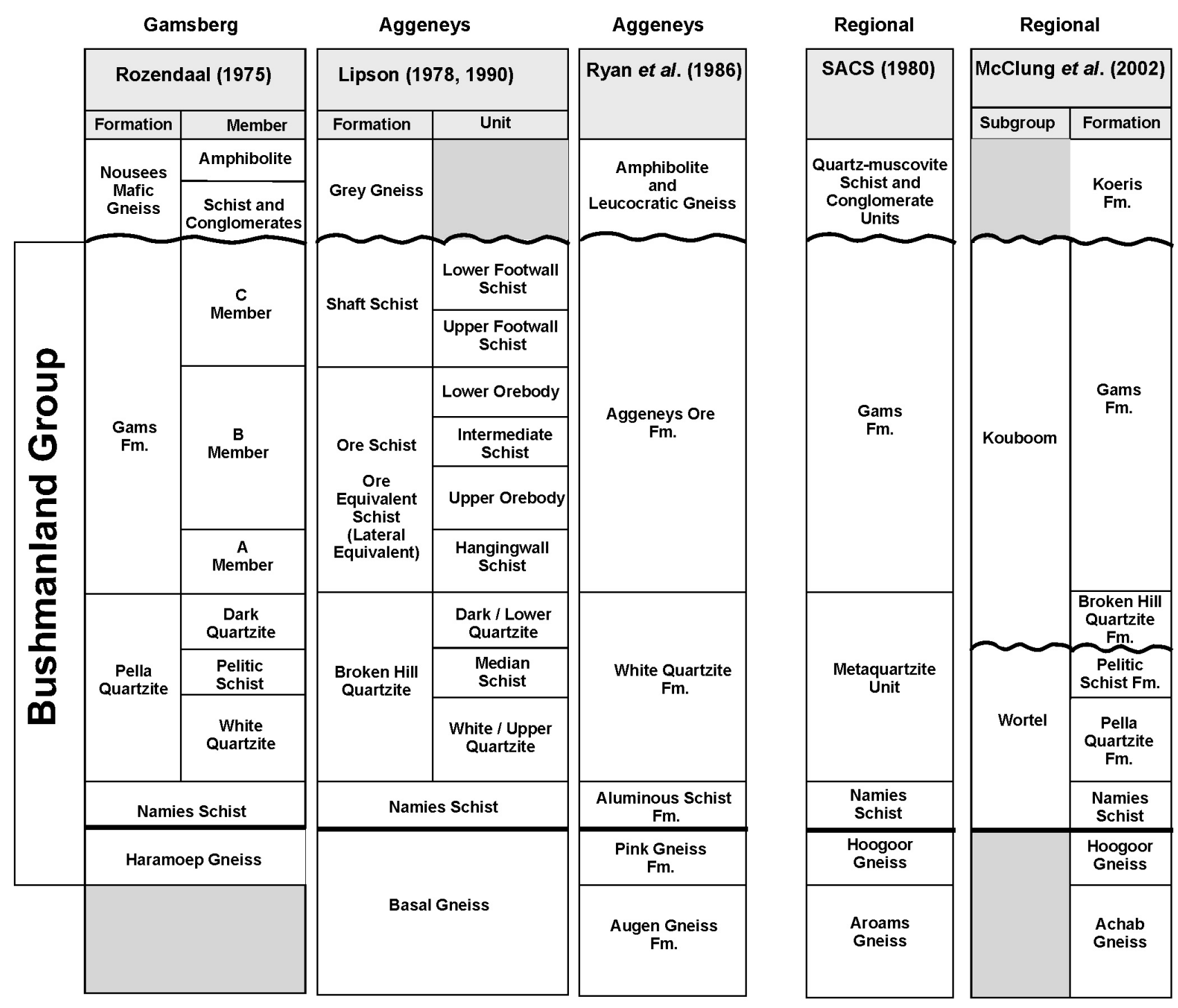

a The thick black line indicates that the contact between the gneisses and metasedimentary succession is typically structural in nature.

units rather than the broad regional subdivisions. Nevertheless, recognition of the units and formations within the Wortel and Kouboom Subgroups based on the regional classification by McClung et al. (2002) (Table 1) is also applied in general discussions and in certain cases. An example of the latter is the use of the Koeris Formation instead of Lipson's Grey Granoblastic Leucocratic Gneiss (Figure 3; Table 1). The regional subgroups will be referred to in discussions of overall geochemical and geochronological trends in the Bushmanland Group. The stratigraphic succession has been overturned at Broken Hill (Lipson, 1990), so that, for e.g., the Dark, or Lower Quartzite is found stratigraphically above the White or Upper Quartzite (Figure 3; Table 1).

\section{Petrography of the Succession}

The Bushmanland Group is an approximately $1000 \mathrm{~m}$ thick succession subdivided at the Broken Hill Mine,
Aggeneys (Lipson, 1990), from oldest to youngest, into the Namies Schist, Broken Hill Quartzite, Ore Schist, Shaft Schist and Koeris Formations (Figure 3; Table 1). The overall succession has been overturned at the Broken Hill Mine (Lipson, 1990). The ore bodies are stratabound in nature (Ryan et al., 1986; Rozendaal, 1986), and are mineralogically complex, containing chalcopyrite, galena, sphalerite, pyrite and pyrrhotite as the most common sulphide minerals (Ryan et al., 1986). The mineralisation at Aggeneys is believed to have been deposited syngenetically (Rozendaal, 1982; Ryan et al., 1986; Moore, 1989; Lipson, 1990; Moore et al., 1990; Hoffmann, 1993). The metapelitic schists consist of sillimanite, biotite, garnet, quartz, muscovite, alkali feldspar and cordierite, with magnetite and ilmenite as the predominant oxides, and apatite, sphene, tourmaline, rutile, anatase, monazite and zircon present in accessory amounts. The stratigraphy is given by Lipson (1990) and is summarized in Figure 3. 


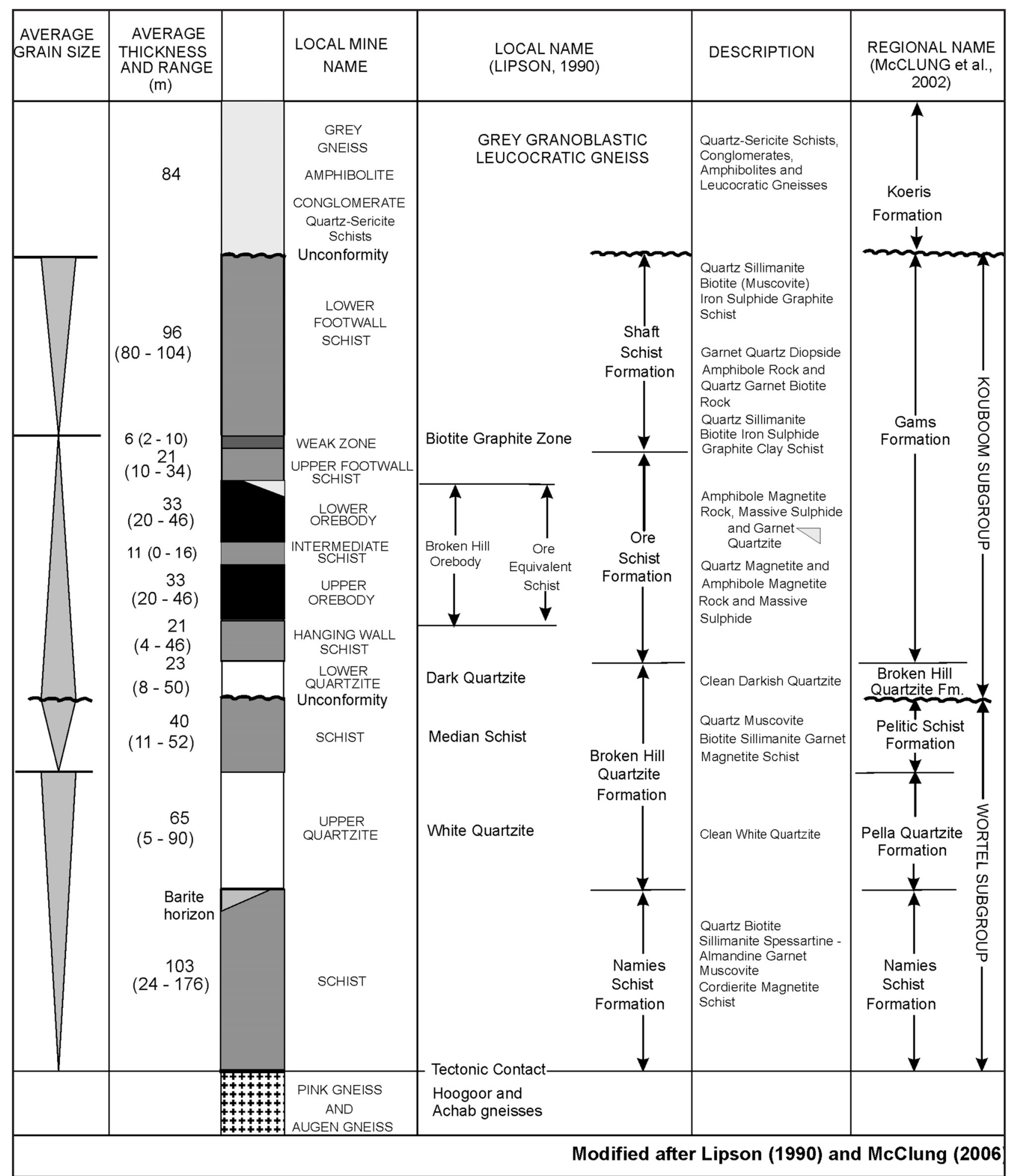

Figure 3. Stratigraphic column at the Broken Hill Mine, Aggeneys. Due to overturning the units have names based on the structural succession found at the mine (modified after Lipson, 1990 and McClung, 2006).

The Namies Schist is a strongly foliated, coarsegrained, grey-green to pink quartzitic biotite-garnetsillimanite schist with sillimanite and biotite locally developed in large concentrations (Ryan et al., 1986; Lipson, 1990). It contains a greater concentration of garnet, cordierite, staurolite and zircon, but less sillimanite, biotite and muscovite than the Shaft Schist.
The Broken Hill Quartzite Formation, comprised of two distinct quartzite horizons (Figure 3), forms the resistant caps to the ranges of hills in the area. The two quartzites are separated into two approximately parallel ridges by an irregular, discontinuous, foliated, banded garnet-sillimanite-biotite-muscovite schist termed the Median Schist (Ryan et al., 1986; Lipson, 1990). The Formation may have either a sharp or gradational 
contact with the overlying Ore Schist Formation (Ryan et al., 1986). The quartzites are of a glassy nature, with minor biotite and muscovite scattered throughout and containing a variety of minor constituents, including thin micaceous muscovite-rich bands, as well as magnetite-, pyrite- and garnet-rich zones, and more rarely tourmaline-, gahnite- and diopside-bearing bands (Moore, 1989). The Dark Quartzite contains more mica and accessory minerals than the White Quartzite, giving rise to its dark nature. Heavy mineral layers, composed of magnetite and biotite, and rich in zircon (Lipson, 1990), along with other sedimentary features, such as cross bedding, are also present (Lipson et al., 1986).

The economically significant Ore Schist Formation (Ryan et al., 1986; Lipson, 1990), containing the massive sulphide and barite deposits associated with iron formations, consists of a succession of quartz-muscovitegarnet-biotite-sillimanite schists (Figure 3), interbanded in places with thin units of micaceous quartzite, calcsilicate rocks and banded iron formations. The Lower Ore Body is significantly more Zn-rich than the Upper Ore Body, and has a smaller metal content (Hoffmann, 1993). The ore bodies and Intermediate Schist grade laterally into the Ore Equivalent Schist (Figure 3) comprised of biotite, garnet, sillimanite, muscovite and quartz.

Light grey to red garnet quartzites, consisting of microbands of quartz, with lesser biotite and muscovite, alternating with garnet-biotite-apatite-rich microbands, are associated with the ore bodies. The rock has a high quartz component $(\geq 70 \%)$ with subordinate garnet and biotite, along with minor apatite, sillimanite, magnetite, alkali feldspar and trace amounts of gahnite, sulphide (mostly sphalerite), chlorite, zircon and zincian staurolite (Hoffmann, 1993).

The Shaft Schist is developed in the structural footwall of the Broken Hill orebody (Figure 3), but rarely outcrops due to its soft nature and negative weathering characteristics (Lipson, 1990). It is a wellfoliated, coarse-grained grey-green graphitic, sulphidic sillimanite-biotite schist. The top of the Kouboom Subgroup is terminated and not well exposed in the Aggeneys area, but drilling has revealed that the Shaft Schist is probably capped by a sequence of muscovite schist, amphibolite and conglomerate (Ryan et al., 1986). This sequence is well developed at Gamsberg, where prominent conglomeratic and amphibolitic horizons occur and have been termed the Koeris Formation (Rozendaal, 1978; McClung et al., 2002; Table 1). The Koeris Formation has been found at stratigraphic levels beneath those of the Namies Schist in certain areas (McClung et al., 2002).

\section{Geochemistry}

\section{Previous Work}

Lipson (1990) and Frimmel et al. (1993) concluded that, apart from some minor variations in the more mobile elements, there have been no significant element transfers across lithological banding during medium- to high-grade metamorphism beyond that which could be expected during metamorphism. The effects of the peak upper amphibolite facies grade of metamorphism on the geochemistry of the metapelitic schists and quartzites will be assumed to be isochemical. Lipson (1990) argued that alteration associated with the mineralisation is restricted to the vicinity of the ore bodies, but noted a greater hydrothermal component within the stratigraphic footwall than in the hanging wall. Stumpfl (1979) and Rozendaal and Stumpfl (1984) described manganese haloes around the Broken Hill and Gamsberg deposits related to the sulphide ore bodies. Hoffmann (1993) investigated the petrology, geochemistry and metamorphism of the Lower Ore Body at the Broken Hill Mine.

\section{Methodology}

Lipson (1990) undertook an extensive and exhaustive lithogeochemical examination of the Bushmanland Group metasediments using XRF-derived whole-rock data, from which the samples used in this study were derived. The major element data used is exclusively that of Lipson (1990). Trace element characterization makes use of both the XRF data of Lipson (1990) and new trace element data derived from inductively coupled plasma mass spectrometry (ICP-MS).

Lipson (1990) gives a detailed account of the sampling procedure, sample preparation and analytical techniques employed for these samples. XRF analyses were performed on Siemens SRS-1 and Phillips PW1400 wavelength dispersive XRF spectrometers. The data of Lipson (1990) used in this paper are recalculated volatile-free.

Twenty-eight Sm-Nd analyses of the metasediments were undertaken. Of these analyses, 23 are from borehole core from the Broken Hill Mine, with the remaining five samples from the Namies- and Shaft-type Schists, and the White- and Dark-type Quartzites, which show similar characteristics to the lithologies at Broken Hill (Lipson, 1990). The $\mathrm{Nd}$ isotopic compositions of selected samples of the Bushmanland Group metasediments were determined in the radiogenic isotope facility of the Department of Geological Sciences, University of Cape Town, using a VG Sector 54 seven-collector thermal ionization mass spectrometer. Single $\mathrm{HF} / \mathrm{HNO}_{3} / \mathrm{HClO}_{4}$ dissolutions of $100 \mathrm{mg}$ of natural (unspiked) whole rock powders were used for measuring Nd isotopic compositions. Rare earth element (REE) separation using cation-exchange columns and $\mathrm{Nd}$ isotopic determination using a double filament technique are those of Zindler (1980) and Zindler et al. (1979)

The ${ }^{143} \mathrm{Nd} /{ }^{144} \mathrm{Nd}$ ratios were corrected for fractionation using ${ }^{146} \mathrm{Nd} /{ }^{144} \mathrm{Nd}=0.72190$ (O'Nions et al. 1977) and normalized to ${ }^{143} \mathrm{Nd} /{ }^{144} \mathrm{Nd}=0.511840$ for the La Jolla standard. Repeat analyses of the La Jolla standard gave ${ }^{143} \mathrm{Nd} /{ }^{144} \mathrm{Nd}=0.511807$. Total system blanks for Nd were found, in general, to be below 200pg and were considered negligible. The $2 \mathrm{~s}_{\text {mean }}$ errors on in- 
Table 2. Selected major element analyses for various lithologies of the Bushmanland Group (after Lipson, 1990). All measured in weight percentage.

\begin{tabular}{|c|c|c|c|c|c|c|c|c|c|c|c|c|c|}
\hline Sample & $\mathrm{SiO}_{2}$ & $\mathrm{TiO}_{2}$ & $\mathbf{A l}_{2} \mathbf{O} 3$ & $\mathrm{Fe}_{2} \mathrm{O}_{3}$ & MnO & MgO & $\mathrm{CaO}$ & $\mathrm{Na}_{2} \mathrm{O}$ & $\mathbf{K}_{2} \mathbf{O}$ & $\mathbf{P}_{2} \mathrm{O}_{5}$ & $\mathrm{H}_{2} \mathrm{O}-$ & LOI & Total \\
\hline \multicolumn{14}{|c|}{ Core Shaft Schist (SS) } \\
\hline ALP 57 & 61.28 & 0.74 & 18.90 & 6.68 & 0.05 & 1.69 & 0.19 & 0.35 & 4.72 & 0.07 & 0.41 & 4.92 & 100.00 \\
\hline ALP 59 & 61.91 & 0.74 & 18.95 & 6.66 & 0.03 & 1.72 & 0.12 & 0.24 & 4.19 & 0.05 & 0.35 & 5.07 & 100.03 \\
\hline ALP 136 & 70.17 & 0.66 & 16.19 & 5.18 & 0.04 & 1.10 & 0.10 & 0.16 & 2.94 & 0.04 & 0.28 & 3.53 & 100.39 \\
\hline ALP 157 & 62.75 & 0.64 & 18.93 & 5.96 & 0.02 & 1.47 & 0.25 & 0.49 & 4.35 & 0.07 & 0.49 & 4.45 & 99.87 \\
\hline \multicolumn{14}{|c|}{ Core Shaft-type Schist (STS) } \\
\hline ALP 422 & 47.47 & 1.13 & 29.12 & 10.06 & 0.22 & 2.42 & 0.10 & 0.10 & 5.05 & 0.08 & 0.40 & 5.25 & 101.40 \\
\hline ALP 424 & 55.92 & 0.99 & 22.28 & 7.83 & 0.11 & 2.48 & 0.13 & 0.11 & 5.18 & 0.08 & 0.52 & 5.12 & 100.75 \\
\hline \multicolumn{14}{|c|}{ Core Namies Schist (NS) } \\
\hline ALP 39 & 82.03 & 0.47 & 9.34 & 4.10 & 0.09 & 0.36 & 0.04 & 0.07 & 2.36 & 0.04 & 0.33 & 1.24 & 100.47 \\
\hline ALP 62 & 69.51 & 0.62 & 15.43 & 5.95 & 0.11 & 0.66 & 0.12 & 0.14 & 4.38 & 0.07 & 0.28 & 2.55 & 99.82 \\
\hline ALP 63 & 69.78 & 0.62 & 15.23 & 6.10 & 0.12 & 0.37 & 0.11 & 0.11 & 4.53 & 0.04 & 0.13 & 2.29 & 99.43 \\
\hline ALP 122 & 70.27 & 0.80 & 14.59 & 8.30 & 0.18 & 0.76 & 0.15 & 0.22 & 3.40 & 0.08 & 0.27 & 1.28 & 100.30 \\
\hline \multicolumn{14}{|c|}{ Surface Namies-type Schist (NTS) } \\
\hline ALP 401 & 70.72 & 0.60 & 14.51 & 5.58 & n.d. ${ }^{\mathrm{a}}$ & 0.95 & 0.09 & 0.11 & 2.82 & 0.04 & 0.58 & 4.25 & 100.25 \\
\hline ALP 403 & 65.46 & 0.53 & 12.97 & 4.23 & n.d. & 0.93 & 0.06 & 0.09 & 1.89 & 0.03 & 0.47 & 13.61 & 100.27 \\
\hline \multicolumn{14}{|c|}{ White Quartzite (WQ) } \\
\hline ALP 40 & 98.61 & 0.06 & 1.07 & 0.67 & n.d. & 0.05 & n.d. & 0.03 & 0.31 & 0.02 & 0.07 & 0.22 & 101.11 \\
\hline ALP 67 & 98.78 & 0.05 & 1.12 & 0.79 & n.d. & 0.09 & n.d. & 0.12 & 0.31 & 0.04 & 0.03 & 0.29 & 100.62 \\
\hline \multicolumn{14}{|c|}{ White-type Quartzite (WTQ) } \\
\hline ALP 432 & 99.75 & 0.02 & 0.45 & 0.18 & n.d. & n.d. & n.d. & n.d. & 0.09 & n.d. & 0.04 & 0.19 & 100.72 \\
\hline ALP 435 & 97.09 & 0.07 & 1.11 & 1.09 & n.d. & n.d. & 0.02 & 0.05 & 0.38 & n.d. & 0.07 & 0.31 & 100.19 \\
\hline \multicolumn{14}{|c|}{ Dark Quartzite (DQ) } \\
\hline ALP 42 & 94.88 & 0.13 & 2.30 & 2.10 & 0.04 & 0.13 & 0.02 & 0.05 & 0.49 & n.d. & 0.13 & 0.36 & 100.63 \\
\hline ALP 69 & 96.17 & 0.07 & 1.55 & 1.65 & 0.03 & 0.05 & 0.02 & 0.04 & 0.51 & n.d. & n.d. & 0.29 & 100.38 \\
\hline \multicolumn{14}{|c|}{ Dark-type Quartzite (DTQ) } \\
\hline ALP 437 & 96.29 & 0.08 & 1.97 & 0.76 & n.d. & n.d. & 0.12 & 0.34 & 0.55 & 0.02 & 0.09 & 0.45 & 100.67 \\
\hline ALP 448 & 92.68 & 0.26 & 3.59 & 1.57 & n.d. & 0.02 & 0.06 & 0.21 & 1.12 & 0.04 & 0.09 & 0.57 & 100.21 \\
\hline \multicolumn{14}{|c|}{ Median Schist (MDS) } \\
\hline ALP 41 & 70.85 & 0.70 & 14.56 & 8.26 & 0.16 & 0.70 & 0.07 & 0.12 & 3.32 & 0.04 & 0.26 & 1.29 & 100.33 \\
\hline ALP 68 & 71.18 & 0.66 & 13.95 & 7.47 & 0.23 & 0.62 & 0.16 & 0.09 & 3.48 & 0.08 & 0.30 & 1.57 & 99.79 \\
\hline \multicolumn{14}{|c|}{ Median-type Schist (MDTS) } \\
\hline ALP 436 & 69.45 & 0.71 & 13.45 & 7.53 & 0.04 & 0.96 & 0.42 & 0.73 & 4.92 & 0.10 & 0.25 & 2.00 & 100.56 \\
\hline ALP 449 & 71.89 & 0.83 & 13.19 & 5.75 & 0.10 & 1.60 & 0.74 & 0.42 & 3.24 & 0.07 & 0.23 & 2.66 & 100.72 \\
\hline \multicolumn{14}{|c|}{ Hangingwall Schist (HS) } \\
\hline ALP 43 & 70.50 & 0.74 & 15.97 & 7.57 & 0.22 & 0.68 & 0.09 & 0.13 & 2.84 & 0.02 & 0.27 & 0.92 & 99.95 \\
\hline ALP 101 & 71.95 & 0.69 & 15.11 & 5.92 & 0.48 & 0.99 & 0.15 & 0.11 & 3.51 & 0.06 & 0.21 & 0.90 & 100.08 \\
\hline ALP 163 & 66.26 & 0.67 & 17.40 & 7.20 & 0.63 & 0.63 & 0.13 & 0.07 & 3.18 & 0.07 & 0.42 & 3.60 & 100.26 \\
\hline \multicolumn{14}{|c|}{ Intermediate Schist (IS) } \\
\hline ALP 76 & 62.83 & 0.82 & 20.48 & 6.35 & 0.30 & 0.92 & 0.08 & 0.14 & 5.62 & 0.06 & 0.40 & 2.07 & 100.07 \\
\hline ALP 177 & 66.27 & 0.75 & 17.53 & 6.75 & 0.48 & 0.73 & 0.09 & 0.10 & 4.74 & 0.07 & 0.31 & 2.78 & 100.60 \\
\hline \multicolumn{14}{|c|}{ Ore Equivalent Schist (OES) } \\
\hline ALP 173 & 62.75 & 0.84 & 18.58 & 9.49 & 0.36 & 1.11 & 0.12 & 0.06 & 3.23 & 0.03 & 0.33 & 3.24 & 100.14 \\
\hline ALP 175 & 63.68 & 0.81 & 18.12 & 8.38 & 0.30 & 0.94 & 0.12 & 0.06 & 3.86 & 0.06 & 0.41 & 3.26 & 100.00 \\
\hline ALP 189 & 64.40 & 0.79 & 17.65 & 6.39 & 0.17 & 1.90 & 0.18 & 0.35 & 4.93 & 0.08 & 0.35 & 2.90 & 100.09 \\
\hline ALP 198 & 74.88 & 0.38 & 9.54 & 9.89 & 0.32 & 0.29 & 0.06 & 0.10 & 1.63 & 0.08 & 0.36 & 2.43 & 99.96 \\
\hline \multicolumn{14}{|c|}{ Upper Footwall Schist (UFS) } \\
\hline ALP 51 & 60.91 & 0.89 & 20.57 & 10.00 & 0.28 & 1.08 & 0.14 & 0.09 & 3.96 & 0.05 & 0.28 & 1.81 & 100.06 \\
\hline ALP 52 & 62.09 & 0.87 & 18.96 & 8.50 & 0.51 & 1.34 & 0.23 & 0.15 & 4.79 & 0.04 & 0.31 & 1.77 & 99.56 \\
\hline ALP 134 & 62.65 & 0.90 & 20.49 & 6.95 & 0.08 & 1.73 & 0.09 & 0.09 & 4.30 & 0.05 & 0.31 & 2.39 & 100.03 \\
\hline ALP 179 & 56.41 & 1.00 & 22.71 & 8.50 & 0.43 & 0.95 & 0.09 & 0.07 & 5.87 & 0.03 & 0.37 & 3.89 & 100.32 \\
\hline
\end{tabular}

${ }^{\mathrm{a}}$ n.d. - not determined or below detection limits 

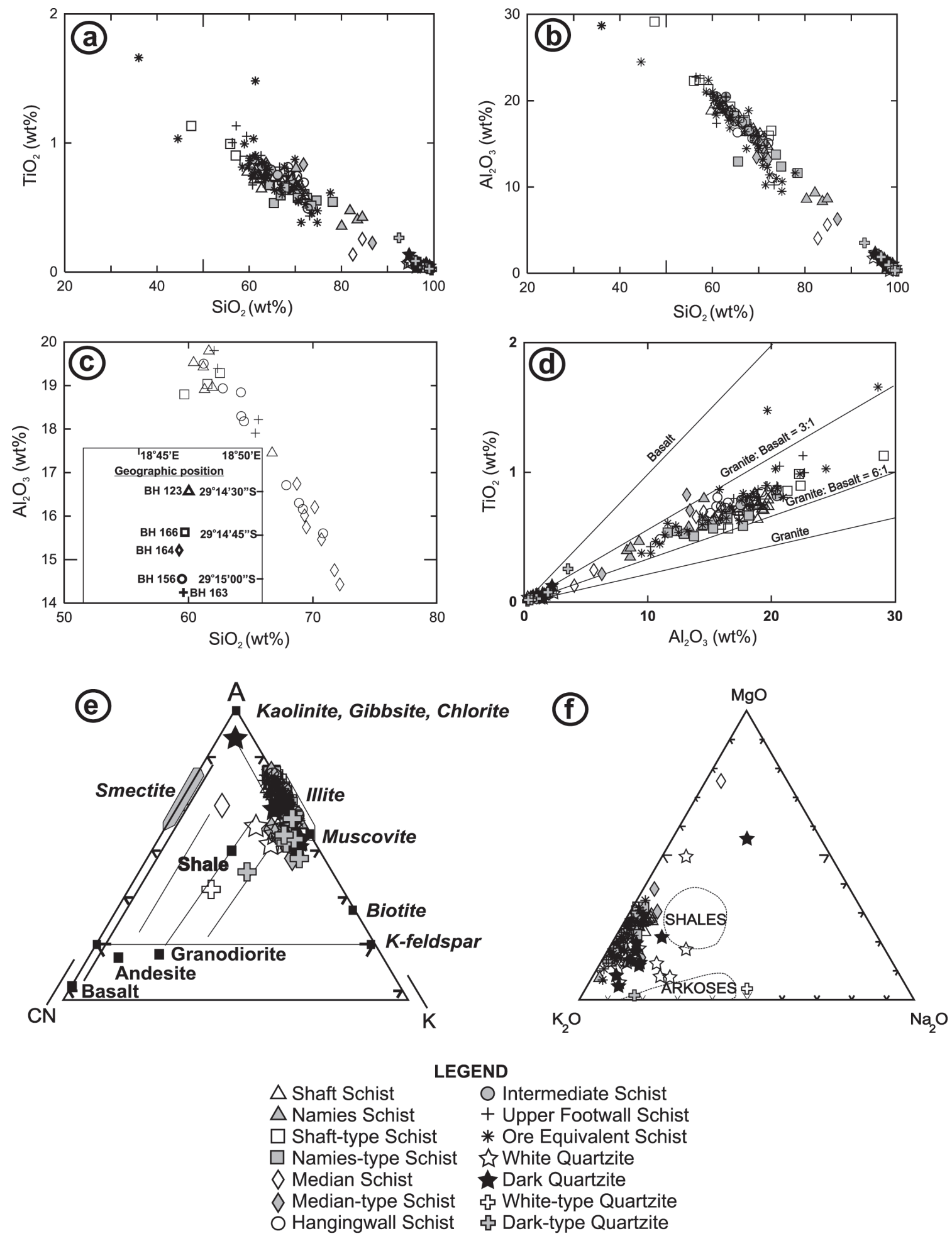

Figure 4. Major element plots for the Bushmanland Group metasediments at the Broken $\mathrm{Hill}_{\mathrm{Mine}}, \mathrm{Aggeneys}$ (a) $\mathrm{TiO}_{2}$ vs. SiO${ }_{2}$. (b) $\mathrm{Al}_{2} \mathrm{O}_{3}$ vs. $\mathrm{SiO}_{2}$. (c) $\mathrm{Al}_{2} \mathrm{O}_{3}$ vs. $\mathrm{SiO}_{2}$ for the Shaft Schist from various boreholes at the Broken Hill Mine. (d) $\mathrm{TiO}_{2}$ vs. $\mathrm{Al}_{2} \mathrm{O}_{3}$. (e) A-CN-K ternary plot (after Nesbitt and Young, 1984; 1989). (f) $\mathrm{K}_{2} \mathrm{O}-\mathrm{MgO}-\mathrm{Na}_{2} \mathrm{O}$ ternary plot illustrating the K-enrichment and Na-depletion of the metasediments. 

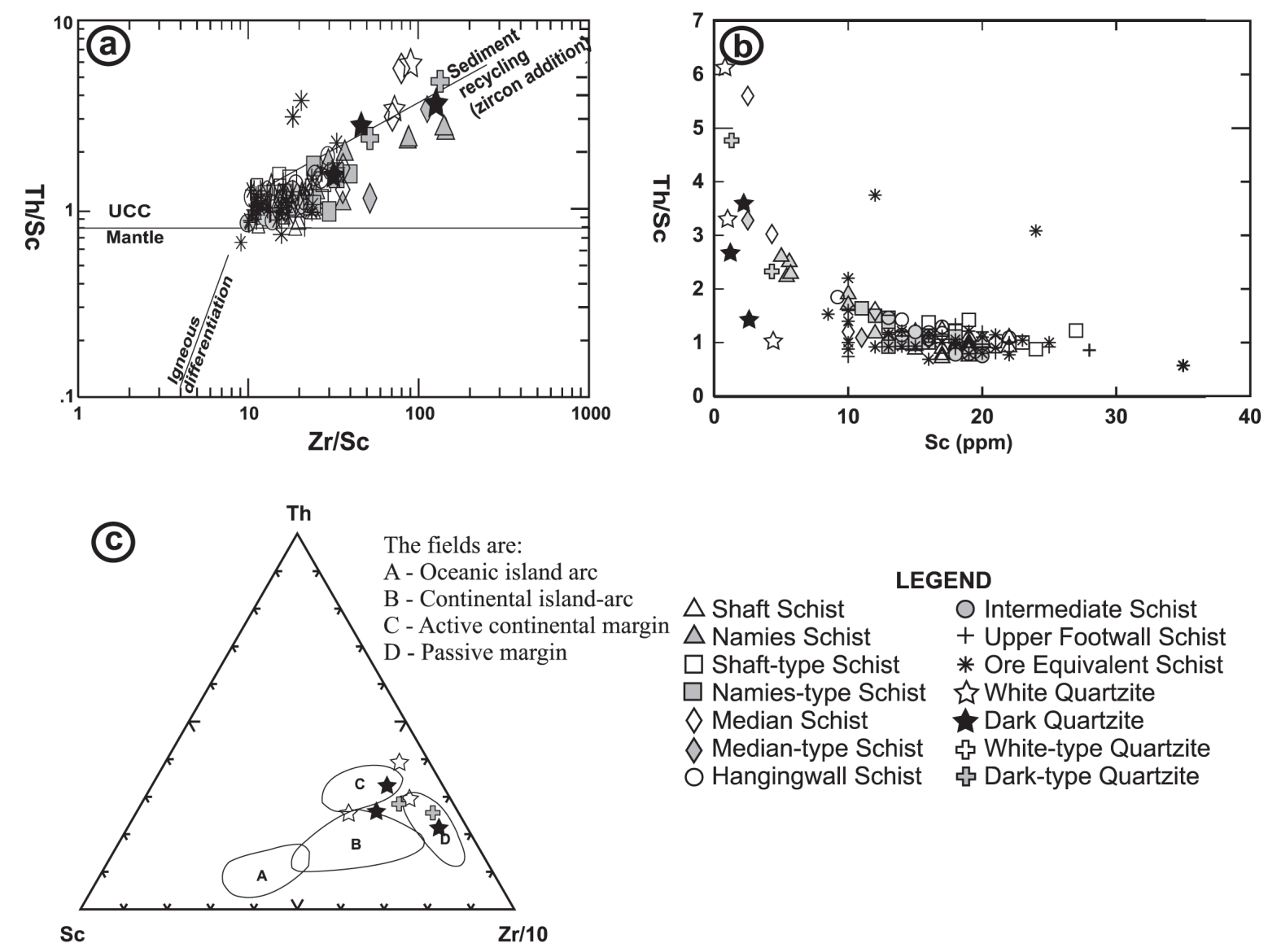

\section{LEGEND}

$\triangle$ Shaft Schist $\quad O$ Intermediate Schist

$\triangle$ Namies Schist $\quad+$ Upper Footwall Schist

$\square$ Shaft-type Schist $\square$ Namies-type Schist

$\diamond$ Median Schist

* Ore Equivalent Schist

$\checkmark$ Median-type Schist \& White-type Quartzite

O Hangingwall Schist § Dark-type Quartzite

Figure 5. Trace element plots for the Bushmanland Group metasediments. (a) Th/Sc vs. $\mathrm{Zr} / \mathrm{Sc}$ indicating a large degree of sediment recycling (after McLennan et al., 1990; 1993). (b) Th/Sc vs. Sc illustrating the contributions from a mafic provenance (represented by high Sc contents and low $\mathrm{Th} / \mathrm{Sc}$ ratios) as opposed to a more felsic provenance (low Sc contents and high $\mathrm{Th} / \mathrm{Sc}$ ratios) for the metasediments. (c) The Th-Sc-Zr/10 tectonic discrimination diagram of Bhatia and Crook (1986) for the Bushmanland Group metaquartzites.

run statistics for ${ }^{143} \mathrm{Nd} /{ }^{144} \mathrm{Nd}$ were generally less than 0.0001. In determining chondrite uniform reservoir (CHUR) model ages the ${ }^{143} \mathrm{Nd} /{ }^{144} \mathrm{Nd}$ value of 0.512638 of Hawkesworth and van Calsteren (1984) and the ${ }^{147} \mathrm{Sm} /{ }^{144} \mathrm{Nd}$ value of 0.1967 for CHUR (today) of Jacobsen and Wasserburg (1980) were used. For determination of depleted mantle reservoir (DM) model ages the depleted mantle curve of DePaolo et al. (1991) was used.

\section{Results}

A few samples of the Namies Schist have higher $\mathrm{SiO}_{2}$ contents of $>80 \mathrm{wt} \%$, compared to the majority with $\mathrm{SiO}_{2}<72$ wt \% (Figure 4; Table 2), suggesting a subgroup of higher mineralogical maturity. For an individual horizon, such as the Shaft Schist, there is a general increase in $\mathrm{SiO}_{2}$ from northwest to southeast within the Broken Hill Mine area (Figure 4c), as also noted by Lipson (1990), reflecting an increase in mineralogical maturity and decrease in the proportion of unstable detrital grains such as feldspar and volcanic rock fragments (Bhatia, 1983). Lipson (1990) noted that the tendency for quartzite to thin southwards through
Aggeneys is matched by progressively cleaner separation in that direction of silica in quartzite from alumina in schist, indicating south-directed progradation over tens of kilometers.

The Namies and Median Schists have similar compositions and tend toward arkosic compositions, and are more sandy and quartzose in nature than the Shaft or Ore Schist Formation metapelites. The Namies Schist has higher $\mathrm{SiO}_{2} / \mathrm{Al}_{2} \mathrm{O}_{3}$ ratios than the Shaft Schist, indicating a greater degree of sediment maturity (Bhatia, 1983) than the more clay-rich Shaft Schist. In addition, the Shaft Schist has a smaller compositional major element range than the Namies Schist (Figure $4 \mathrm{a}$ and b).

Lipson (1990) defined the Namies-type and Shafttype Schists as the regional equivalents of the Namies and Shaft Schists respectively as these lithologies, developed at Wortel, Namiesberg and elsewhere within the Aggeneys District away from the Broken Hill Mine at Aggeneys, show similar geochemical characteristics to those developed at Broken Hill (Figure 4). Similarly, clean and dark-coloured quartzites developed in the Wortel and Namiesberg areas have been termed the White-type and Dark-type Quartzites by Lipson (1990). 
Table 3. Selected trace element analyses for the metapelitic schists and quartzites of the Bushmanland Group. All measured in parts per million (ppm)

\begin{tabular}{|c|c|c|c|c|c|c|c|c|c|c|c|c|c|c|}
\hline SAMPLE & $\mathbf{R b}$ & $\mathbf{B a}$ & Th & $\mathbf{U}$ & $\mathbf{K}$ & $\mathbf{N b}$ & La & Sr & $\mathbf{P}$ & Hf & $\mathbf{Z r}$ & Ti & $\mathbf{Y}$ & Sc \\
\hline \multicolumn{15}{|c|}{ Core Shaft Schist (SS) } \\
\hline $\operatorname{ALP} 57^{\mathrm{a}}$ & 186 & 450 & 20.7 & 4.45 & 50108 & 12.0 & 43.8 & 59.7 & 493 & 5.19 & 177 & 927 & 12 & 14 \\
\hline $\operatorname{ALP} 59^{\mathrm{a}}$ & 187 & 404 & 20.4 & 4.96 & 44481 & 14.1 & 44.1 & 44.0 & 352 & 6.22 & 212 & 937 & 14 & 16 \\
\hline ALP 136 & 199 & 276 & 14 & n.d. ${ }^{b}$ & 31211 & 14 & 24 & 15 & 282 & n.d. & 347 & 826 & 20 & 15 \\
\hline ALP 157 & 231 & 559 & 15 & 4.6 & 46180 & 13 & 36 & 49 & 493 & n.d. & 180 & 801 & 26 & 17 \\
\hline \multicolumn{15}{|c|}{ Core Shaft-type Schist (STS) } \\
\hline ALP 422 & 342 & 573 & 33 & n.d. & 53611 & 40 & 70 & 8.9 & 564 & n.d. & 410 & 1415 & 40 & 27 \\
\hline ALP 424 & 289 & 726 & 21 & 5 & 54991 & 25 & 43 & 15 & 564 & n.d. & 259 & 1240 & 44 & 24 \\
\hline \multicolumn{15}{|c|}{ Core Namies Schist (NS) } \\
\hline $\operatorname{ALP} 39^{\mathrm{a}}$ & 112 & 217 & 13.6 & 2.52 & 25054 & 12.4 & 44.3 & 5.83 & 282 & 8.12 & 294 & 588 & 24 & 5.0 \\
\hline ALP 62 & 232 & 3358 & 17 & n.d. & 46498 & 16 & 44 & 22 & 493 & n.d. & 286 & 776 & 42 & 10 \\
\hline $\operatorname{ALP} 63^{\mathrm{a}}$ & 208 & 3413 & 19.3 & 4.54 & 48091 & 16.3 & 50.2 & 13.4 & 282 & 5.5 & 192 & 776 & 28 & 11 \\
\hline ALP 122 & 223 & 414 & 14 & n.d. & 36095 & 19 & 42 & 21 & 564 & n.d. & 486 & 1002 & 29 & 14 \\
\hline \multicolumn{15}{|c|}{ Surface Namies-type Schist (NTS) } \\
\hline ALP 401 & 195 & 486 & 15 & n.d. & 29937 & 14 & 30 & 23 & 282 & n.d. & 338 & 751 & 25 & 15 \\
\hline ALP 403 & 181 & 252 & 18 & n.d. & 20064 & 15 & 29 & 17 & 211 & n.d. & 416 & 664 & 30 & 13 \\
\hline \multicolumn{15}{|c|}{ White Quartzite (WQ) } \\
\hline $\operatorname{ALP} 40^{\mathrm{a}}$ & 15.9 & 23.7 & 3.03 & 0.66 & 3291 & 1.77 & 10.70 & 0.93 & 141 & 2.49 & 92.0 & 75 & 5 & 1 \\
\hline ALP 67 & 17 & 24 & n.d. & n.d. & 3291 & 2.1 & 8 & n.d. & 282 & n.d. & 101 & 63 & 7 & n.d. \\
\hline \multicolumn{15}{|c|}{ White-type Quartzite (WTQ) } \\
\hline ALP 432 & 5.3 & 4.5 & n.d. & n.d. & 955 & n.d. & 5 & n.d. & n.d. & n.d. & 50 & 25 & 3 & n.d. \\
\hline ALP 435 & 23 & 43 & n.d. & n.d. & 4034 & 3.1 & 11 & 3.5 & n.d. & n.d. & 280 & 88 & 8 & 1 \\
\hline \multicolumn{15}{|c|}{ Dark Quartzite (DQ) } \\
\hline $\operatorname{ALP} 42^{\mathrm{a}}$ & 27.7 & 43.6 & 8.1 & 1.53 & 5202 & 4.33 & 23.00 & 1.04 & n.d. & 5.41 & 206 & 163 & 7 & 2 \\
\hline ALP 69 & 26 & 48 & 3.8 & n.d. & 5414 & n.d. & 12 & 2.1 & n.d. & n.d. & 119 & 88 & 8 & n.d. \\
\hline \multicolumn{15}{|c|}{ Dark-type Quartzite (DTQ) } \\
\hline ALP 437 & 32 & 64 & 6.2 & n.d. & 5839 & 4.4 & 16 & 8.9 & 141 & n.d. & 166 & 100 & 7 & 1 \\
\hline ALP 448 & 55 & 232 & 10 & n.d. & 11890 & 6.5 & 12 & 14 & 282 & n.d. & 213 & 326 & 12 & 4 \\
\hline \multicolumn{15}{|c|}{ Median Schist (MDS) } \\
\hline $\operatorname{ALP} 41^{\mathrm{a}}$ & 165 & 264 & 16.8 & 3.0 & 35245 & 17.3 & 37.5 & 6.54 & 282 & 6.4 & 223 & 876 & 14.9 & 8 \\
\hline ALP 68 & 213 & 410 & 12 & n.d. & 36944 & 18 & 34 & 17 & 564 & n.d. & 345 & 826 & 34 & 10 \\
\hline \multicolumn{15}{|c|}{ Median-type Schist (MDTS) } \\
\hline ALP 436 & 285 & 609 & 12 & n.d. & 52231 & 18 & 34 & 70 & 704 & n.d. & 551 & 889 & 28 & 11 \\
\hline ALP 449 & 199 & 705 & 17 & n.d. & 34396 & 17 & 31 & 83 & 493 & n.d. & 295 & 1039 & 37 & 16 \\
\hline \multicolumn{15}{|c|}{ Hangingwall Schist (HS) } \\
\hline $\operatorname{ALP} 43^{\mathrm{a}}$ & 170 & 403 & 22.4 & 2.94 & 30150 & 18.5 & 52.00 & 5.55 & 141 & 5.10 & 178 & 927 & 21.9 & 12 \\
\hline ALP 101 & 194 & 636 & 19 & n.d. & 37262 & 17 & n.d. & 15 & 423 & n.d. & 309 & 864 & 36 & 13 \\
\hline ALP 163 & 175 & 392 & 19 & 3.9 & 33759 & 16 & n.d. & 15 & 493 & n.d. & 201 & 839 & 41 & 16 \\
\hline \multicolumn{15}{|c|}{ Intermediate Schist (IS) } \\
\hline ALP 76 & 307 & 2049 & 15 & n.d. & 59662 & 19 & 38 & 33 & 423 & n.d. & 228 & 1027 & 29 & 19 \\
\hline ALP 177 & 242 & 611 & 14 & n.d. & 50320 & 17 & 36 & 21 & 493 & n.d. & 238 & 939 & 42 & 18 \\
\hline \multicolumn{15}{|c|}{ Ore Equivalent Schist (OES) } \\
\hline $\operatorname{ALP} 173^{\mathrm{a}}$ & 205 & 309 & 22.0 & 3.07 & 34290 & 23.1 & 50.9 & 6.80 & 211 & 6.11 & 215 & 1052 & 30.4 & 19 \\
\hline ALP 175 & 236 & 432 & 19 & n.d. & 40978 & 19 & 28 & 8.1 & 423 & n.d. & 298 & 1014 & 36 & 18 \\
\hline ALP 189 & 269 & 788 & 18 & n.d. & 52337 & 18 & 35 & 30 & 564 & n.d. & 277 & 989 & 33 & 18 \\
\hline ALP 198 & 113 & 985 & 13 & n.d. & 17304 & 11 & n.d. & 16 & 564 & n.d. & 225 & 476 & 20 & 9 \\
\hline \multicolumn{15}{|c|}{ Upper Footwall Schist (UFS) } \\
\hline ALP 51 & 290 & 727 & 24 & n.d. & 42040 & 22 & 41 & 13 & 352 & n.d. & 229 & 1114 & 31 & 20 \\
\hline $\operatorname{ALP} 52^{\mathrm{a}}$ & 205 & 511 & 20.7 & 2.93 & 50851 & 20.1 & 49.5 & 25.4 & 282 & 5.00 & 171 & 1089 & 27.1 & 12 \\
\hline ALP 134 & 258 & 503 & 22 & n.d. & 45649 & 22 & n.d. & 20 & 352 & n.d. & 239 & 1127 & 28 & 22 \\
\hline ALP 179 & 319 & 664 & 17 & n.d. & 62316 & 24 & 37 & 15 & 211 & n.d. & 227 & 1252 & 33 & 21 \\
\hline
\end{tabular}

${ }^{a}$ ICP-MS analysis (this study), the rest Lipson (1990); b n.d. not determined or below detection limits 
The Bushmanland Group metasediments have intermediate to high $\mathrm{K}_{2} \mathrm{O}$, intermediate $\mathrm{SiO}_{2}$ and $\mathrm{Al}_{2} \mathrm{O}_{3}$, low $\mathrm{Fe}_{2} \mathrm{O}_{3 \mathrm{~T}}$ and $\mathrm{TiO}_{2}$, and intermediate to low $\mathrm{Nb}, \mathrm{Rb}$ and Th contents suggestive of a felsic igneous provenance rather than the low major element and high $\mathrm{SiO}_{2}, \mathrm{Y}, \mathrm{Nb}, \mathrm{Rb}, \mathrm{Th}, \mathrm{Ba}$ and $\mathrm{Zr}$ contents of a recycled provenance (Lacassie et al., 2004). $\mathrm{TiO}_{2}$ and $\mathrm{Al}_{2} \mathrm{O}_{3}$ correlate with each other for all the metapelitic schists and quartzites (Figure $4 \mathrm{~d}$ ). As the $\mathrm{TiO}_{2} / \mathrm{Al}_{2} \mathrm{O}_{3}$ ratios of basaltic rocks are considerably higher than those for granitic rocks the $\mathrm{TiO}_{2} / \mathrm{Al}_{2} \mathrm{O}_{3}$ ratios of between 3 and 6 for the metasediments indicates that they were derived from a predominantly granitic to granodioritic provenance. The low $\mathrm{La} / \mathrm{Th}$ ratio (1.8) of the Bushmanland Group suggests a strongly fractionated, felsic provenance (Lipson, 1990). In addition, the high $\mathrm{Th} / \mathrm{Sc}, \mathrm{Zr} / \mathrm{Th}, \mathrm{La} / \mathrm{Sc}$ and $\mathrm{Ti} / \mathrm{Zr}$ ratios, in excess of upper continental crustal (UCC) values (McLennan et al., 2006), indicate derivation from a felsic igneous provenance, which would be richer in Th and La, than mafic igneous or clay-dominated provenances, rich in Sc and $\mathrm{Cr}$ (Condie and Wronkiewicz, 1990; McLennan and Taylor, 1991; McLennan et al., 1993).
Weathering trends of rocks of granitic / rhyolitic to granodioritic composition give rise to rocks of similar composition to those of the metapelitic schists and quartzites, which tend toward the composition of kaolinite (Figure 4e). Lipson (1990) argued that the degree of weathering did not proceed fully to the kaolin stage due to $\mathrm{Rb} / \mathrm{K}_{2} \mathrm{O}$ ratios that, although exceeding that of average shale, are not as high as in kaolinite. The schists are notably Na-depleted (Figure 4f), and fall along the advanced weathering trend, either as having been derived from illite or smectite-bearing clays (Lipson, 1990; Hoffmann, 1993; Figure 4e), or as a consequence of Na-depletion and Al-enrichment associated with some form of alteration ( $c f$. Willner et al., 1990), be it provenance derived or postdeposition. The high $\mathrm{Th} / \mathrm{Sc}$ ratios of $>1$ for the Namies and Shaft Schists, above upper crustal values of 0.79 (Taylor and McLennan, 1985; Figure 5a), also suggest that the metasediments were derived from a provenance that had undergone a significant degree of weathering, with subsequent reworking.

The metapelitic schists and quartzites are K-enriched and Na-depleted relative to typical shale compositions,
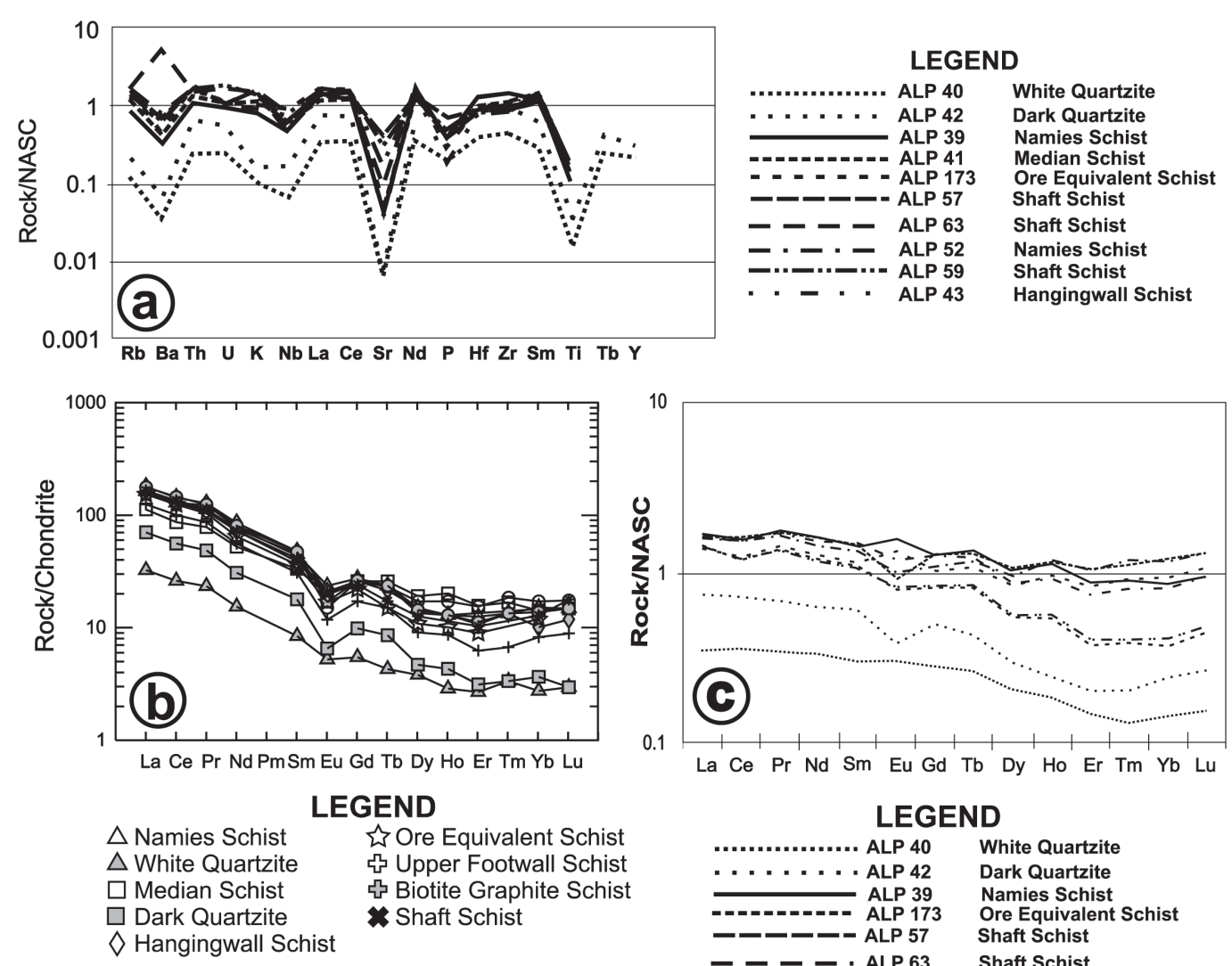

La Ce Pr Nd Sm Eu Gd Tb Dy Ho Er Tm Yb Lu

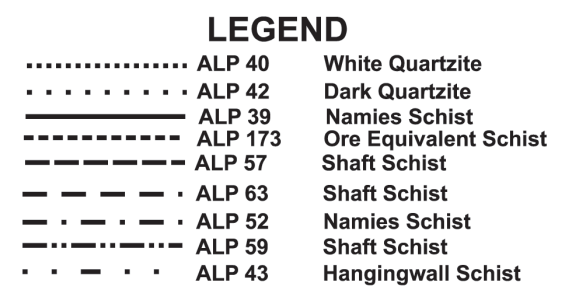

Figure 6. Trace element concentration (spider) diagrams and rare earth element (REE) plots for the Bushmanland Group metasediments. (a) NASC-normalised spider diagram. (b) Chondrite-normalised REE plot using the chondrite values of Nakamura (1974) with additional values from Boynton (1984). (c) NASC-normalised REE plot. 
Table 4. REE contents of the Bushmanland Group metapelitic schists and quartzites determined by ICP-MS.

\begin{tabular}{|c|c|c|c|c|c|c|c|c|c|c|c|c|c|c|}
\hline Sample & $\mathbf{L a}$ & Ce & Pr & Nd & Sm & $\mathbf{E u}$ & Gd & $\mathbf{T b}$ & Dy & Ho & Er & Tm & $\mathbf{Y b}$ & Lu \\
\hline \multicolumn{15}{|c|}{ Namies Schist (NS) } \\
\hline ALP 39 & 44.3 & 83.0 & 11.3 & 38.3 & 6.91 & 1.64 & 5.61 & 0.91 & 4.62 & 1.00 & 2.69 & 0.45 & 2.90 & 0.49 \\
\hline ALP 63 & 50.2 & 101.0 & 13.6 & 46.4 & 8.52 & 1.95 & 6.98 & 1.15 & 5.74 & 1.17 & 2.85 & 0.44 & 2.66 & 0.43 \\
\hline \multicolumn{15}{|c|}{ White Quartzite (WQ) } \\
\hline ALP 40 & 10.7 & 23.8 & 2.71 & 9.99 & 1.8 & 0.38 & 1.53 & 0.22 & 1.14 & 0.19 & 0.48 & 0.07 & 0.44 & 0.07 \\
\hline \multicolumn{15}{|c|}{ Dark Quartzite (DQ) } \\
\hline ALP 42 & 23.0 & 48.0 & 5.35 & 19.2 & 3.64 & 0.48 & 2.72 & 0.36 & 1.64 & 0.25 & 0.66 & 0.10 & 0.75 & 0.12 \\
\hline \multicolumn{15}{|c|}{ Hangingwall Schist (HS) } \\
\hline ALP 43 & 52.0 & 105.0 & 13.9 & 47.2 & 8.80 & 1.50 & 6.92 & 1.03 & 4.73 & 0.95 & 2.41 & 0.40 & 2.51 & 0.43 \\
\hline \multicolumn{15}{|c|}{ Ore Equivalent Schist (OES) } \\
\hline ALP 173 & 50.9 & 110.0 & 13.6 & 48.7 & 8.78 & 1.15 & 7.08 & 1.08 & 5.82 & 1.19 & 3.45 & 0.55 & 3.74 & 0.59 \\
\hline \multicolumn{15}{|c|}{ Upper Footwall Schist (UFS) } \\
\hline ALP 52 & 49.5 & 104.0 & 12.8 & 43.4 & 8.01 & 1.25 & 6.00 & 0.99 & 5.28 & 1.22 & 3.39 & 0.58 & 3.65 & 0.60 \\
\hline \multicolumn{15}{|c|}{ Shaft Schist (SS) } \\
\hline ALP 57 & 43.8 & 80.8 & 10.7 & 35.5 & 6.37 & 1.02 & 4.56 & 0.69 & 3.04 & 0.55 & 1.23 & 0.19 & 1.14 & 0.20 \\
\hline \multirow[t]{2}{*}{ ALP 59} & 44.1 & 81.5 & 10.6 & 35.3 & 6.34 & 1.04 & 4.66 & 0.71 & 3.10 & 0.58 & 1.32 & 0.20 & 1.28 & 0.22 \\
\hline & \multicolumn{2}{|l|}{$(\mathrm{La} / \mathrm{Ce})_{\mathrm{N}}$} & \multicolumn{2}{|l|}{$\left(\mathrm{Ce} / \mathrm{Ce}^{*}\right)$} & $(\mathbf{L a} / \mathrm{Sm})_{\mathrm{N}}$ & \multicolumn{2}{|r|}{$\left(\mathbf{E u} / \mathbf{E u} \mathbf{u}^{*}\right)$} & \multicolumn{2}{|r|}{$(\mathbf{G d} / \mathbf{Y b})_{\mathbf{N}}$} & \multicolumn{3}{|c|}{$(\mathbf{L a} / \mathbf{Y b})_{\mathbf{N}}$} & \multicolumn{2}{|c|}{ ¿REE } \\
\hline NS & \multicolumn{2}{|c|}{1.31 to 1.40} & \multicolumn{2}{|l|}{0.86 to 0.90} & 3.64 to 3.96 & \multicolumn{2}{|r|}{0.78 to 0.81} & \multicolumn{2}{|r|}{1.54 to 2.09} & \multicolumn{3}{|c|}{10.22 to 12.62} & \multicolumn{2}{|c|}{204 to 243} \\
\hline WQ & \multicolumn{2}{|l|}{1.18} & \multicolumn{2}{|l|}{1.02} & 3.67 & \multicolumn{2}{|r|}{0.70} & \multicolumn{2}{|r|}{2.77} & \multicolumn{3}{|c|}{16.26} & \multicolumn{2}{|c|}{53.5} \\
\hline DQ & \multicolumn{2}{|l|}{1.26} & \multicolumn{2}{|l|}{1.00} & 3.90 & & 0.47 & & 2.89 & & 20.5 & & & 6.3 \\
\hline HS & 1.30 & & 0.90 & & 3.65 & & 0.59 & & 2.20 & & 13.85 & & & 7.8 \\
\hline OES & 1.22 & & 0.97 & & 3.58 & & 0.51 & & 1.51 & & 9.10 & & & 6.6 \\
\hline UFS & 1.25 & & 0.96 & & 3.81 & & 0.55 & & 1.31 & & 9.07 & & & 0.7 \\
\hline SS & 1.42 to 1.4 & & 0.86 to 0.8 & & 4.24 to 4.29 & & 0.58 to 0.59 & & 2.90 to 3.19 & & 23.03 to 25.70 & & 190 & O 191 \\
\hline NASC & & & & & & & & & & & 6.7 & & & \\
\hline PAAS & & & & & & & & & & & 9.1 & & & \\
\hline
\end{tabular}

such as the North American Shale Composite (NASC) (Gromet et al., 1984) or the Post Archean Australian Shale (PAAS) (McLennan, 1989) (Figure 4f), a feature also noted by Moore (1989) for the metapelitic schists and quartzites on a regional scale for the western Namaqua Province.

The Namies Schist and Broken Hill Quartzite Formations of the Wortel Subgroup have higher La, Nb, $\mathrm{Zr}$, Sm and Th/Sc, and lower Th, Ti, Cr, Sc and Ti/Nb than the Ore Schist and Shaft Schist Formations of the overlying Kouboom Subgroup (Figure 5b). The Shaft Schist has an exceptionally high $\mathrm{S}, \mathrm{Cr}$ and $\mathrm{V}$ content. Lipson (1990) argued that an anoxic reducing depositional environment may be deduced for the Shaft Schist due to its high S and C content.

The quartzites plot exclusively in the passive margin field of the greywacke tectonic discrimination diagrams of Bhatia and Crook (1986) due to sediment recycling and / or reworking that has increased their $\mathrm{Zr}$ contents (Figure 5c). Lipson (1990) argued that a passive continental margin environment may be deduced from the extreme silica purity and sheet-like morphology of the quartz arenitic Broken Hill Quartzite Formation and from the elevated alumina concentrations of the Namies and Shaft Schists.

Relative to the NASC, and plotted according to the order of Wood et al. (1979) (Figure 6a), the metasediments show relatively flat to slightly fractionated patterns, with most samples strongly depleted in $\mathrm{Ba}, \mathrm{Sr}$ and $\mathrm{Ti}$ and with lower $\mathrm{Nb}$ and $\mathrm{P}$ contents, and slight enrichment in the light rare earth elements (LREE), $\mathrm{Zr}$ and $\mathrm{Hf}$ indicating derivation from a more fractionated, quartzofeldspathic provenance than that which gave rise to the NASC. Winchester and Max (1989) noted that passive margin profiles are similar to post-Archean continental shale profiles, such as NASC or PAAS, and therefore have a flat trend.

Chondrite-normalised REE patterns (Figure 6b) exhibit typical LREE-enriched, HREE-depleted sediment patterns with strong negative $\mathrm{Eu}$ anomalies $\left(\mathrm{Eu} / \mathrm{Eu}^{*}<1\right)$ for the metasediments, with a leveling off toward Lu and moderate HREE fractionation $\left((\mathrm{Gd} / \mathrm{Yb})_{\mathrm{N}}=1.5\right.$ to 3.0$)$ (Table 4). The Dark Quartzite has a higher REE content than the White Quartzite due to a larger heavy mineral content. The former also has a larger negative $\mathrm{Eu}$ anomaly than the latter. Relative to NASC (Gromet et al., 1984) (Figure 6c) the metapelitic schists and quartzites have flat REE patterns with slight LREE enrichment and HREE depletion, being more fractionated than either NASC or PAAS (Table 4). The Namies Schist and the White Quartzite have positive Eu anomalies, whereas the Shaft Schist has markedly negative Eu anomalies and is more fractionated in its REE pattern than the Namies Schist relative to NASC. The metasediments show more fractionated signatures than NASC in their REE patterns (Figure 6c), suggesting more fractionated 
Table 5. Sm-Nd isotopic data for the Bushmanland Group

\begin{tabular}{|c|c|c|c|c|c|c|c|c|c|c|c|}
\hline Sample I & Lithology & $\begin{array}{c}\text { Sm } \\
\text { ppm }\end{array}$ & $\begin{array}{c}\text { Nd } \\
\text { ppm }\end{array}$ & $\mathrm{Sm} / \mathrm{Nd}$ & $\begin{array}{l}{ }^{147} \mathrm{Sm} / \\
{ }^{144} \mathrm{Nd}\end{array}$ & $\begin{array}{l}{ }^{143} \mathrm{Nd} / \\
{ }^{144} \mathrm{Nd}\end{array}$ & $f^{\mathrm{Sm} / \mathrm{Nd}}$ & $\varepsilon_{\mathrm{Nd}(0)}$ & $\begin{array}{c}{ }^{143} \mathrm{Nd} / \\
{ }^{144} \mathrm{Nd}(t){ }^{\mathrm{a}}\end{array}$ & $\varepsilon_{\mathrm{Nd}(t)}$ & $\begin{array}{c}\mathbf{T}_{\mathbf{D M}} \\
\mathbf{M a}\end{array}$ \\
\hline ALP 39 & NS & 7.0 & 38.9 & 0.180 & 0.11315 & 0.51166 & -0.42 & -19.9 & 0.51047 & -2.76 & 2251 \\
\hline ALP 41 & MDS & 7.5 & 40.4 & 0.186 & 0.11756 & 0.51153 & -0.40 & -22.43 & 0.51029 & -6.22 & 2558 \\
\hline ALP 43 & HS & 8.8 & 47.6 & 0.185 & 0.11731 & 0.51155 & -0.40 & -22.04 & 0.51032 & -5.78 & 2520 \\
\hline ALP 52 & UFS & 8.5 & 47.4 & 0.179 & 0.11354 & 0.51154 & -0.42 & -22.24 & 0.51035 & -5.19 & 2441 \\
\hline ALP 53 & BGZ & 7.3 & 40.8 & 0.179 & 0.11253 & 0.51147 & -0.43 & -23.60 & 0.51029 & -6.36 & 2521 \\
\hline ALP 57 & SS & 6.1 & 34.2 & 0.178 & 0.11243 & 0.51148 & -0.43 & -23.41 & 0.51030 & -6.14 & 2503 \\
\hline ALP 59 & SS & 6.6 & 36.7 & 0.180 & 0.11287 & 0.51147 & -0.43 & -23.60 & 0.51028 & -6.43 & 2529 \\
\hline ALP 63 & NS & 8.7 & 48.1 & 0.181 & 0.11438 & 0.51159 & -0.42 & -21.26 & 0.51039 & -4.39 & 2385 \\
\hline ALP 67 & WQ & 1.6 & 9.2 & 0.174 & 0.11224 & 0.51154 & -0.43 & -22.24 & 0.51036 & -4.93 & 2410 \\
\hline ALP 68 & MDS & 7.7 & 41.8 & 0.184 & 0.11604 & 0.51145 & -0.41 & -23.99 & 0.51023 & -7.47 & 2641 \\
\hline ALP 75 & IF - UOB & 3.1 & 7.2 & 0.431 & 0.26965 & & 0.37 & & & & \\
\hline ALP 76 & IS & 8.7 & 50.0 & 0.174 & 0.10991 & 0.51143 & -0.44 & -24.38 & 0.51027 & -6.60 & 2516 \\
\hline ALP 101 & HS & 7.6 & 42.5 & 0.179 & 0.11338 & 0.51147 & -0.42 & -23.60 & 0.51028 & -6.53 & 2542 \\
\hline ALP 122 & NS & 8.8 & 49.2 & 0.179 & 0.11350 & 0.51162 & -0.42 & -20.68 & 0.51043 & -3.62 & 2319 \\
\hline ALP 125 & MDS & 5.5 & 20.0 & 0.275 & 0.17359 & 0.51193 & -0.12 & -14.63 & 0.51010 & -9.93 & \\
\hline ALP 127 & OES & 7.7 & 41.8 & 0.184 & 0.11604 & 0.51147 & -0.41 & -23.60 & 0.51025 & -7.08 & 2611 \\
\hline ALP 134 & UFS & 9.3 & 53.1 & 0.175 & 0.11124 & 0.51146 & -0.43 & -23.80 & 0.51029 & -6.29 & 2504 \\
\hline ALP 136 & SS & 5.2 & 29.1 & 0.179 & 0.11301 & 0.51144 & -0.43 & -24.19 & 0.51025 & -7.04 & 2577 \\
\hline ALP 141 & SS & 5.2 & 28.9 & 0.180 & 0.11379 & 0.51128 & -0.42 & -27.31 & 0.51008 & -10.34 & 2838 \\
\hline ALP 147 & IS & 9.9 & 53.7 & 0.184 & 0.11670 & 0.51152 & -0.41 & -22.63 & 0.51029 & -6.24 & 2551 \\
\hline ALP 164 & HS & 10.2 & 56.0 & 0.182 & 0.11536 & 0.51151 & -0.41 & -22.82 & 0.51030 & -6.16 & 2531 \\
\hline ALP $172 \mathrm{~g}$ & OEGQ & 7.2 & 32.3 & 0.223 & 0.14155 & 0.51180 & -0.28 & -17.16 & 0.51031 & -5.87 & 2838 \\
\hline ALP 177 & IS & 8.2 & 44.2 & 0.186 & 0.11781 & 0.51157 & -0.40 & -21.65 & 0.51033 & -5.49 & 2502 \\
\hline ALP 402 & NTS & 4.4 & 24.3 & 0.181 & 0.11555 & 0.51148 & -0.41 & -23.41 & 0.51026 & -6.78 & 2582 \\
\hline ALP 403 & STS & 3.6 & 19.5 & 0.185 & 0.11513 & 0.51146 & -0.41 & -23.80 & 0.51025 & -7.09 & 2602 \\
\hline ALP 422 & STS & 12.2 & 69.8 & 0.175 & 0.11053 & 0.51145 & -0.44 & -23.99 & 0.51145 & -6.34 & 2501 \\
\hline ALP 435 & WTQ & 1.0 & 5.0 & 0.200 & 0.11968 & 0.51157 & -0.39 & -21.65 & 0.51031 & -5.87 & 2551 \\
\hline ALP 448 & DTQ & 2.3 & 12.1 & 0.190 & 0.12073 & 0.51146 & -0.39 & -23.80 & 0.51019 & -8.24 & 2757 \\
\hline
\end{tabular}

a Assuming time $(t)$ to be $1600 \mathrm{Ma}$, BGZ - biotite graphite zone, IF-VOB - Iron formation upper ore body, OEGQ - ore equivalent garnet quartzite.

quartzofeldspathic provenances than average shale (Lipson, 1990).

\section{Sm-Nd Isotope Geochemistry}

A full table of Sm-Nd isotope data including $\mathrm{T}_{\mathrm{CHUR}}$ and $\mathrm{T}_{\mathrm{DM}}$ model ages, as well as $\varepsilon_{\mathrm{Nd}(\mathrm{t})}$ values, is given in Table $5 . \mathrm{Sm} / \mathrm{Nd}$ ratios vary between 0.17 and 0.20 , in general, with higher ratios present in the garnet quartzite sample ALP 172g, the iron formation sample ALP 75 and a sample of Median Schist (ALP 125) from Maanhaarkop, which also has much higher ${ }^{143} \mathrm{Nd} /{ }^{144} \mathrm{Nd}$ ratios than the other metasediments. The Namies Schist, in general, has younger depleted mantle model ages $\left(\mathrm{T}_{\mathrm{DM}}\right)$ compared to those of the Ore and Shaft Schist Formation metapelites and the regional rocks (Figure $7 \mathrm{~d}$; Table 5).

Based on the single zircon $\mathrm{U}-\mathrm{Pb}$ ages obtained in this study (see later) a value of $1.6 \mathrm{Ga}$ is taken as the age of deposition of the Bushmanland Group in order to determine $\varepsilon_{\mathrm{Nd}(\mathrm{t})}$ values. The metasediments have similar $f^{\mathrm{Sm} / \mathrm{Nd}}$ values, but show a range of $\varepsilon_{\mathrm{Nd}(\mathrm{t})}$ values (Figure 7b) denoting a degree of mixing in the metasediments (Bock et al., 1994). The Namies Schist and White Quartzite have the highest $\varepsilon_{\mathrm{Nd}(\mathrm{t})}$ values suggesting derivation from a more depleted provenance, whereas the Shaft Schist has lower $\varepsilon_{\mathrm{Nd}(\mathrm{t})}$ values suggesting derivation from a more enriched, crustal-type provenance. Samples ALP 172g and ALP 125 plot away from this horizontal trend toward higher $f^{\mathrm{Sm} / \mathrm{Nd}}$ values and greater degrees of LREE depletion. The metasediments were derived from fractionated provenances, as denoted by low $f^{\mathrm{Sm} / \mathrm{Nd}}$ values.

The Sm-Nd model ages indicate that the Bushmanland Group metasediments have a provenance with mantle separation ages of $\sim 2.5$ to $\sim 1.8 \mathrm{Ga}\left(\mathrm{T}_{\mathrm{CHUR}}\right)$ or $\sim 2.85$ to $\sim 2.25 \mathrm{Ga}\left(\mathrm{T}_{\mathrm{DM}}\right.$ ) (Figure $7 \mathrm{c}$ and d; Table 5 ). The Namies Schist has younger $\mathrm{T}_{\mathrm{DM}}$ model ages $(\sim 2.39$ to $\sim 2.25 \mathrm{Ga}$ - Table 5) than the other metasediments, which generally have older $\mathrm{T}_{\mathrm{DM}}$ model ages ranging between $\sim 2.4 \mathrm{Ga}$ and $\sim 2.65 \mathrm{Ga}$ and older. This reflects the younger zircon ages (Table 6; Figures $8 \mathrm{a}$ and 9) and differing chemistry of the Namies Schist compared to the other metapelitic schists or the quartzites. The regional metapelites and quartzites have older model ages than those at Aggeneys (Figures 7c and d).

\section{Geochronology}

\section{Methodology}

For the geochronological investigation, crushed samples of 1 to $2 \mathrm{~kg}$ were subjected to routine heavy mineral separation. The zircons were hand-picked, mounted in 

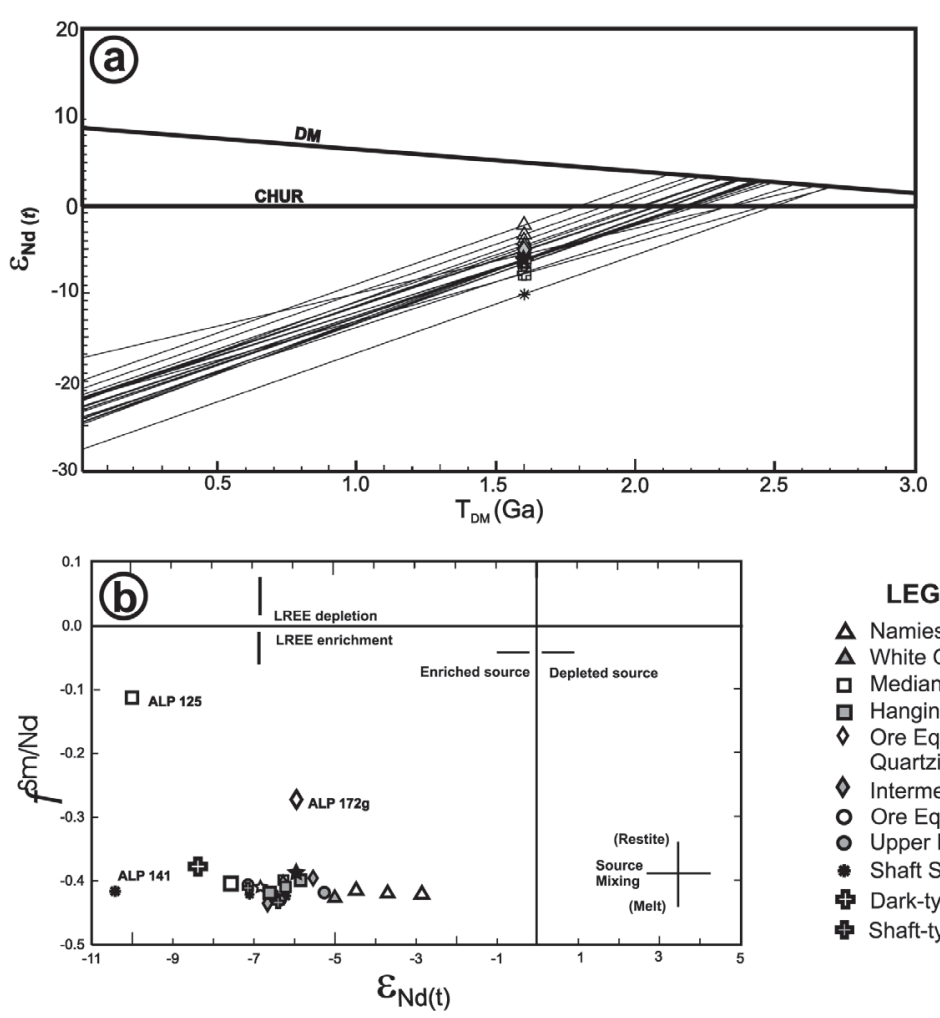

\section{LEGEND}

$\Delta$ Namies Schist

$\Delta$ White Quartzite

口 Median Schist

口 Hangingwall Schist

Ore Equivalent Garnet

Quartzite

Intermediate Schist

O Ore Equivalent Schist

O Ore Equivalent Schist
O Upper Footwall Schist

- Shaft Schist

Dark-type Quartzite

\$ Shaft-type Schist
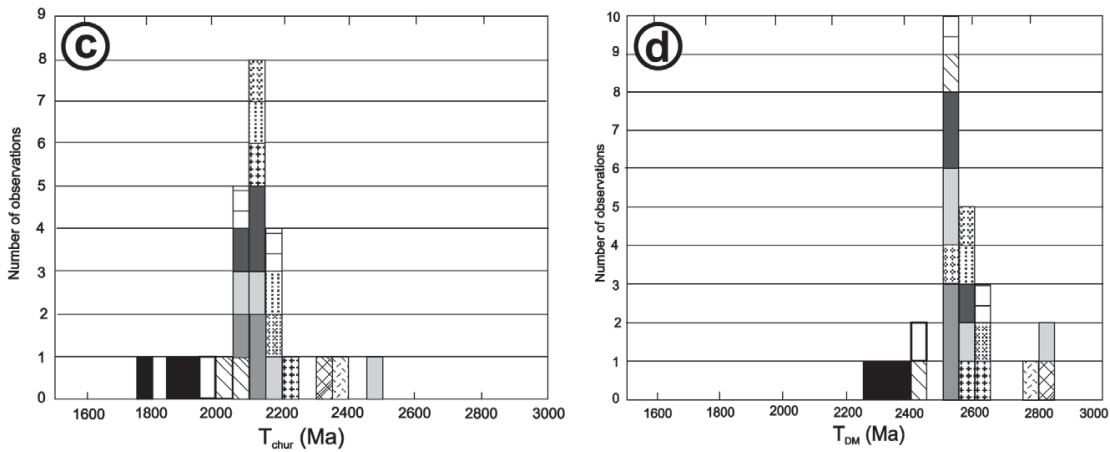

LEGEND

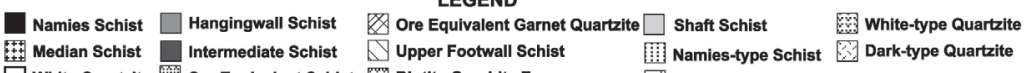

+1 Median Schist Intermediate Schist Upper Footwall Schist

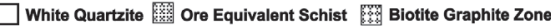

Shaft-type Schist

Figure 7. Sm-Nd isotope systematics of the Bushmanland Group metasediments. (a) $\varepsilon_{\mathrm{Nd}(\mathrm{t})}$ vs. $\mathrm{T}_{\mathrm{DM}}$ (after De Paolo et al., 1991). (b) $f^{\mathrm{Sm} / \mathrm{Nd}}$ vs. $\varepsilon_{\mathrm{Nd}(\mathrm{t})}$. (c) $\mathrm{T}_{\mathrm{CHUR}}$ histogram for the metasediments. (d) $\mathrm{T}_{\mathrm{DM}}$ histogram.

epoxy and polished, prior to analysis using the Sensitive High Resolution Ion Microprobe (SHRIMP II), housed at the Research School of Earth Sciences at The Australian National University in Canberra. Details of SHRIMP analytical methods are given by Compston et al. (1984), Williams and Claesson (1987) and Williams (1998). The methodology used in this study is that given by Robb et al. (1999).

Metasedimentary lithologies from the Bushmanland Group were subjected to the geochronological investigation. Six metasediment samples and one amphibolite were selected to represent a section through the Bushmanland Group stratigraphy. All but two of the metasedimentary samples came from borehole core through the Broken Hill Mine succession, with the amphibolite sampled from surface outcrop at Gamsberg and the Dark-type Quartzite from borehole core drilled at Namiesberg (Figure 2). Geochronological data tables can be found as supplemental data on the GeoScience World website at the following address: http://sajg.geoscienceworld.org.

The internal structure of the zircon grains was characterised using a scanning electron microscope to detect cathodoluminescent (CL) and backscattered electron (BSE) contrast. These images were collected at the Electron Microscopy Unit, the University of Cape Town, as well as at the Research School of Earth Sciences, the Australian National University. 

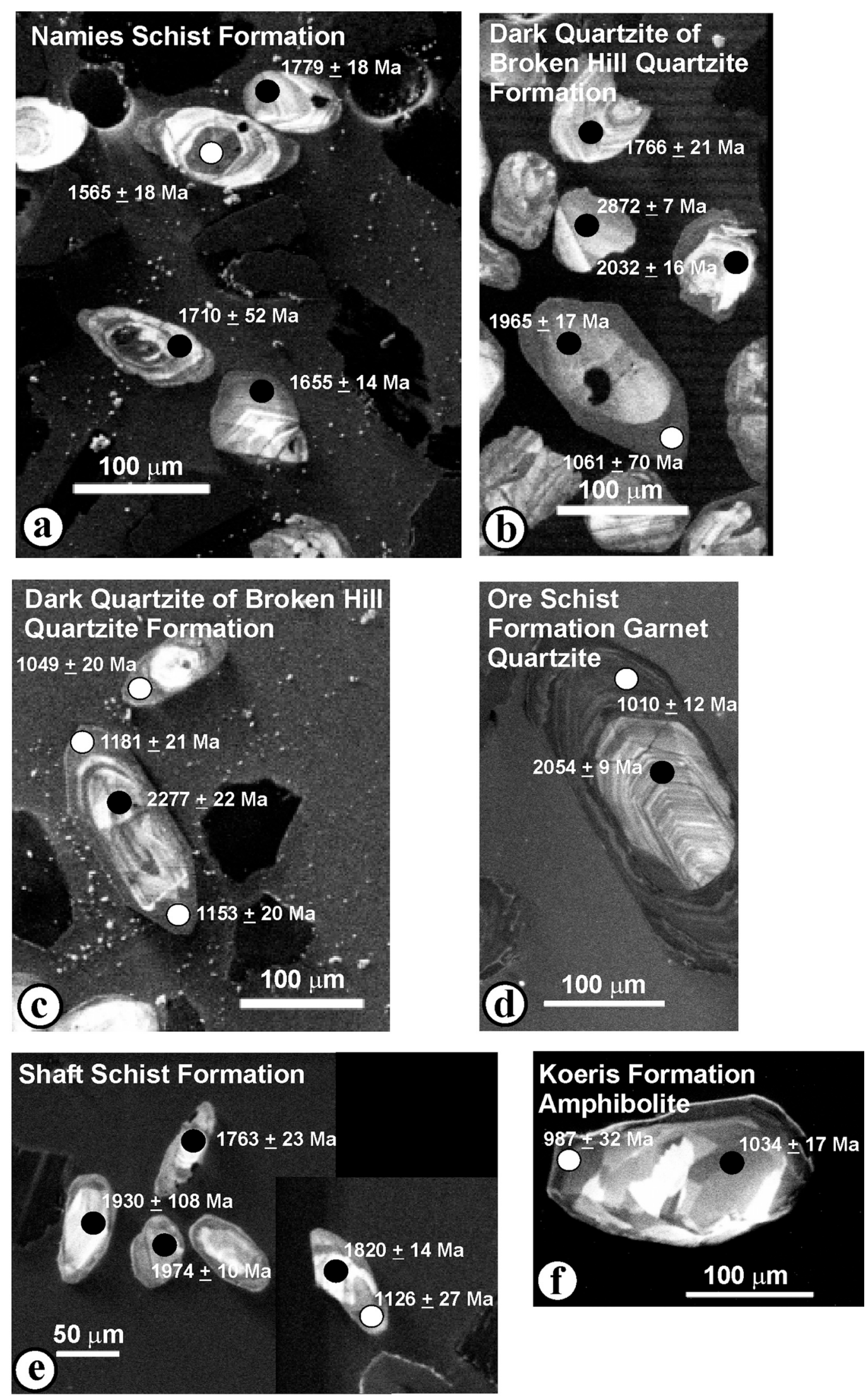

Figure 8. Cathodoluminescent (CL) images of the detrital zircons showing analysed spots. (a) Namies Schist (ALP 39). (b) and (c) Dark Quartzite (ALP 42). (d) Ore Garnet Quartzite (ALP 114). (e) Shaft Schist (ALP 136). (f) Koeris Formation amphibolite (Gams-4). 


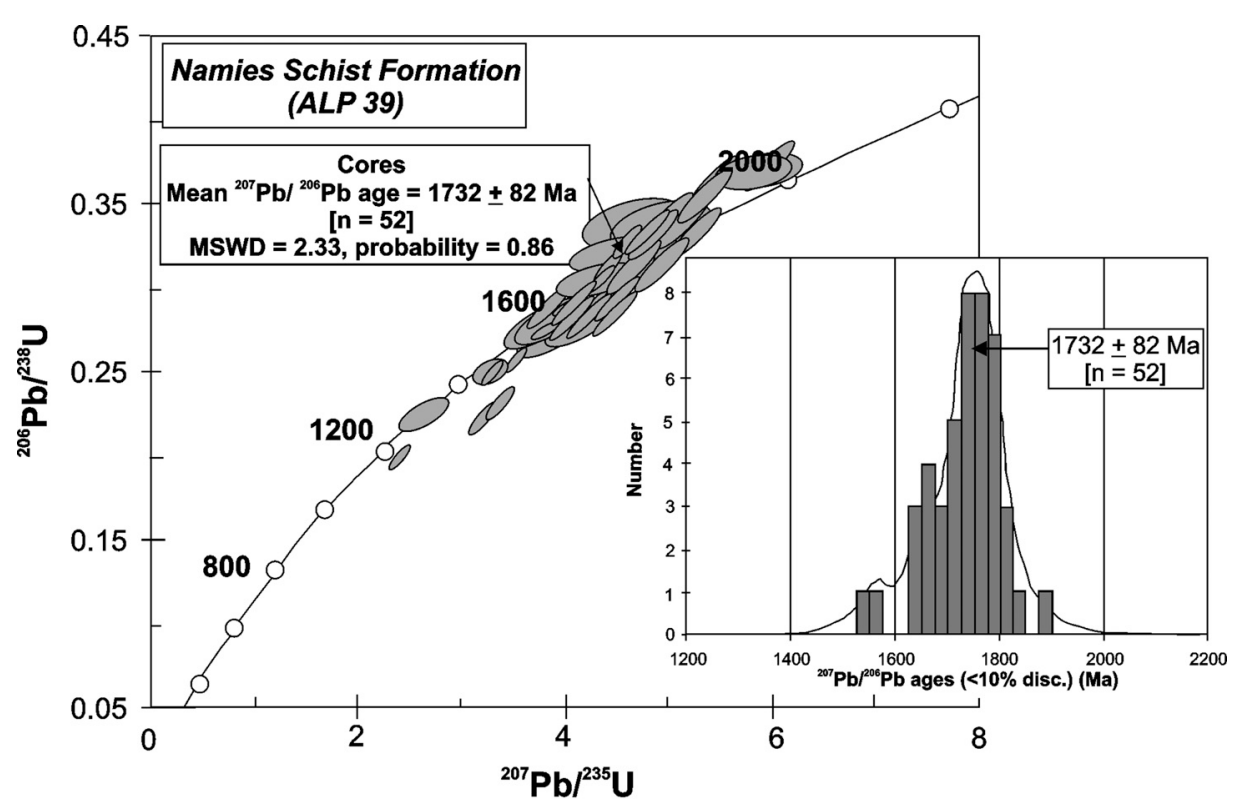

Figure 9. U-Pb concordia diagram for zircons from Namies Schist (ALP 39) from the Broken Hill Mine, Aggeneys. The inset shows a histogram of ${ }^{207} \mathrm{~Pb} /{ }^{206} \mathrm{~Pb}$ ages for this sample.

Errors in the data tables and figures are at the 68\% confidence level $(1 \sigma)$, with final weighted mean ages reported at the $95 \%$ confidence level. Decay constants used were $1.55125 \times 10^{-10}\left({ }^{238} \mathrm{U}\right)$ and $9.8485 \times 10^{-10}$ $\left({ }^{235} \mathrm{U}\right)$. Statistical analysis and $\mathrm{U}-\mathrm{Pb}$ Concordia diagrams were generated using Isoplot (Version 2.49) (Ludwig, 2001).

\section{Namies Schist Formation}

A sample of metapelitic Namies Schist (ALP 39) was sampled from borehole BH123 at the Broken Hill Mine (Figure 2). The zircons exhibit simple weak concentric zonation patterns of a uniform brightness (Figure $8 \mathrm{a}$ ). Dark, unzoned rims are present in some grains, but these have not resorbed the concentrically zoned cores. Some dark cores that have been resorbed and overgrown by bright concentrically zoned overgrowths are present but are not common. Unzoned transgressive patches do not occur. Dark veins crosscut the zircons in places, but do not disrupt the zonation pattern.

The zircons show a limited age range with a unimodal distribution (Figure 9; Table A1). Rejecting results with greater than $10 \%$ discordancy that show large degrees of Pb-loss, and excluding a result with an age of $1391 \pm 19 \mathrm{Ma}$ (analysis 7.2, Table A1), which is significantly younger than the bulk of the detrital zircon ages, gives an age of $1732 \pm 82 \mathrm{Ma}(\mathrm{MSWD}=2.33$, prob $=0.86)(n=52)$. Two analyses give concordant ages of $\sim 1640 \mathrm{Ma}$ (analyses 1.2 and 2.1, Table A1), which are the youngest detrital zircon ages in the Bushmanland Group at Aggeneys. A very limited number of grains have ages less than $\sim 1.4 \mathrm{Ga}$ (Figure 9) and with low $\mathrm{Th} / \mathrm{U}$ ratios of less than 0.1 represent metamorphic overgrowths (Connelly, 2000) or analyses that overlapped onto metamorphic overgrowths and rims. The restricted provenance age is also illustrated as a histogram in Figure 9.

\section{Dark Quartzite of Broken Hill Quartzite Formation}

Previous investigations of the zircons from a heavy mineral layer in the quartzite at Froneman se Kop to the east of the Broken Hill inselberg (Figure 2), described by Lipson et al. (1986) as sedimentary cross-bedding, produced a large range of highly discordant analyses (Armstrong et al., 1988). No concordia intercept could be constructed, but geologically recent Pb-loss has caused a spread of data away from an $\sim 2.0$ to $\sim 1.8 \mathrm{Ga}$ grouping.

A sample of Dark Quartzite (ALP 42) from borehole BH123 at the Broken Hill Mine was taken for geochronological investigation in order to get better results for the age of the provenance to the quartzites than that obtained by Armstrong et al. (1988). The zircons are typically bright, weakly zoned to unzoned and of a uniform intensity (Figure $8 \mathrm{~b}$ and c). Any dark cores that may be present have been resorbed and overgrown by bright, weakly zoned to unzoned overgrowths. Numerous grains contain large dark, unzoned overgrowths and rims, which have overgrown and resorbed the bright core areas (Figures $8 \mathrm{~b}$ and c). These dark rims commonly result in euhedral grain shapes for the zircons. The dark unzoned rims are far more abundant, and of a greater volume than found within the Namies Schist sample described above.

The detrital zircons have a predominantly bimodal age distribution, with ages concentrated between $\sim 2.15$ and $\sim 1.95 \mathrm{Ga}$, and between $\sim 1.9$ and $\sim 1.75 \mathrm{Ga}$ (Figure 10), 


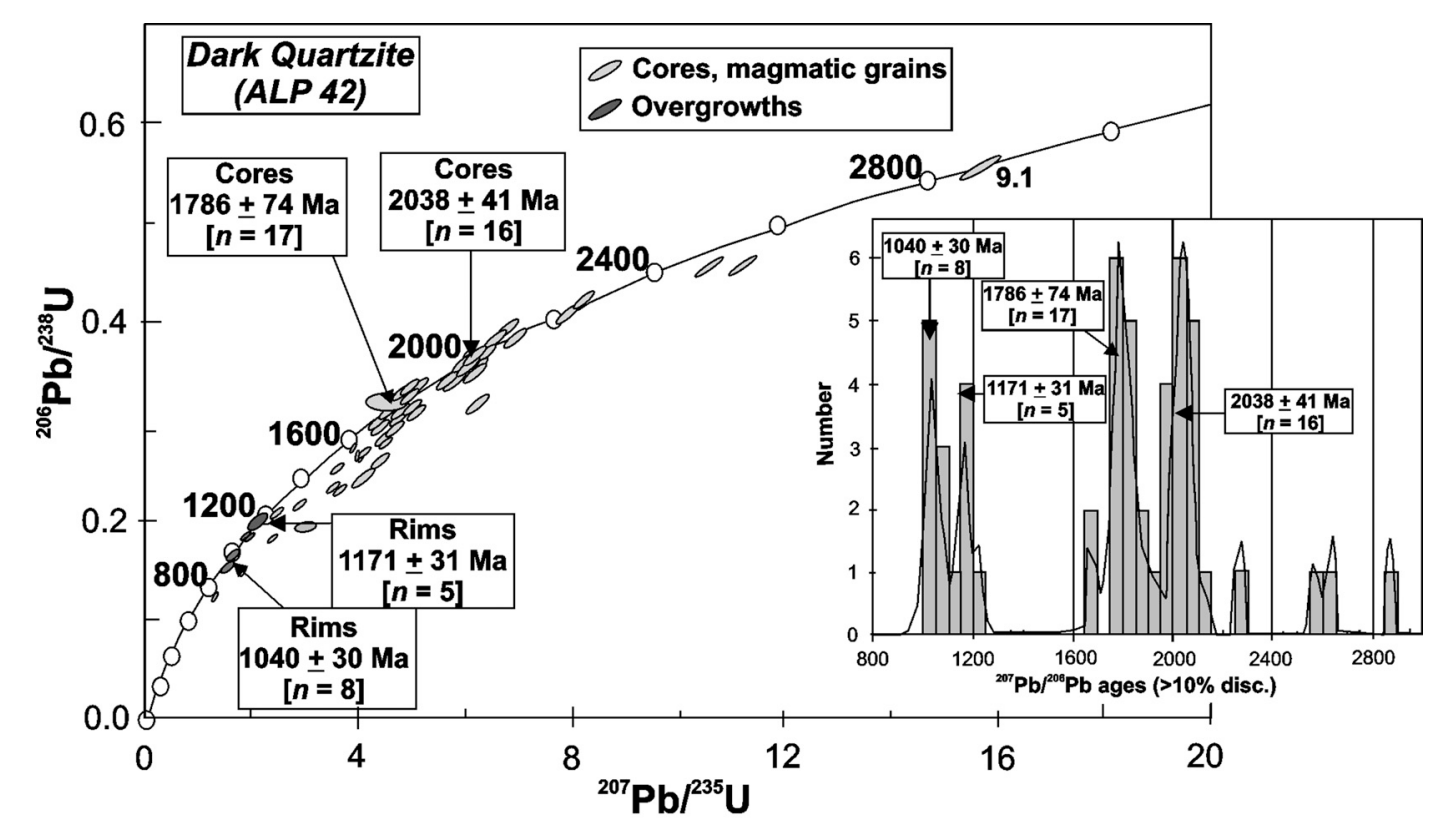

Figure 10. U-Pb concordia diagram for zircons from Dark Quartzite (sample ALP 42) from the Broken Hill Mine, Aggeneys. The inset shows a histogram of ${ }^{207} \mathrm{~Pb} /{ }^{206} \mathrm{~Pb}$ ages for this sample.

with geologically recent Pb-loss creating a degree of scatter in the concordia plot. The older grouping has an age of $2038 \pm 41 \mathrm{Ma}(n=16, \mathrm{MSWD}=0.92)$, with the younger grouping having an age of $1786 \pm 74 \mathrm{Ma}$ ( $n=17$, MSWD $=0.80)$. The younger grouping is within error of the detrital zircons within the Namies Schist sample (ALP 39) described above.

Another grouping of between $\sim 1.25$ and $\sim 1.0$ Ga (Figure 10) is mostly of metamorphic overgrowths
(Table A2). Within this younger age grouping there are two sub-groupings, the first having an age of $1171 \pm 31$ Ma $(n=5$, MSWD $=0.10)$. The second gives an age of $1040 \pm 30 \mathrm{Ma}(n=8$, MSWD $=0.14)$. Only one nonmetamorphic grain (analysis 54.1), characterised by higher $\mathrm{Th} / \mathrm{U}$ ratios typical of magmatic growth, gives a younger age of $1144 \pm 73 \mathrm{Ma}$, outside the two main detrital age groupings. Older detrital zircons with ages older than $\sim 2.2 \mathrm{Ga}$ also occur, but are mostly highly

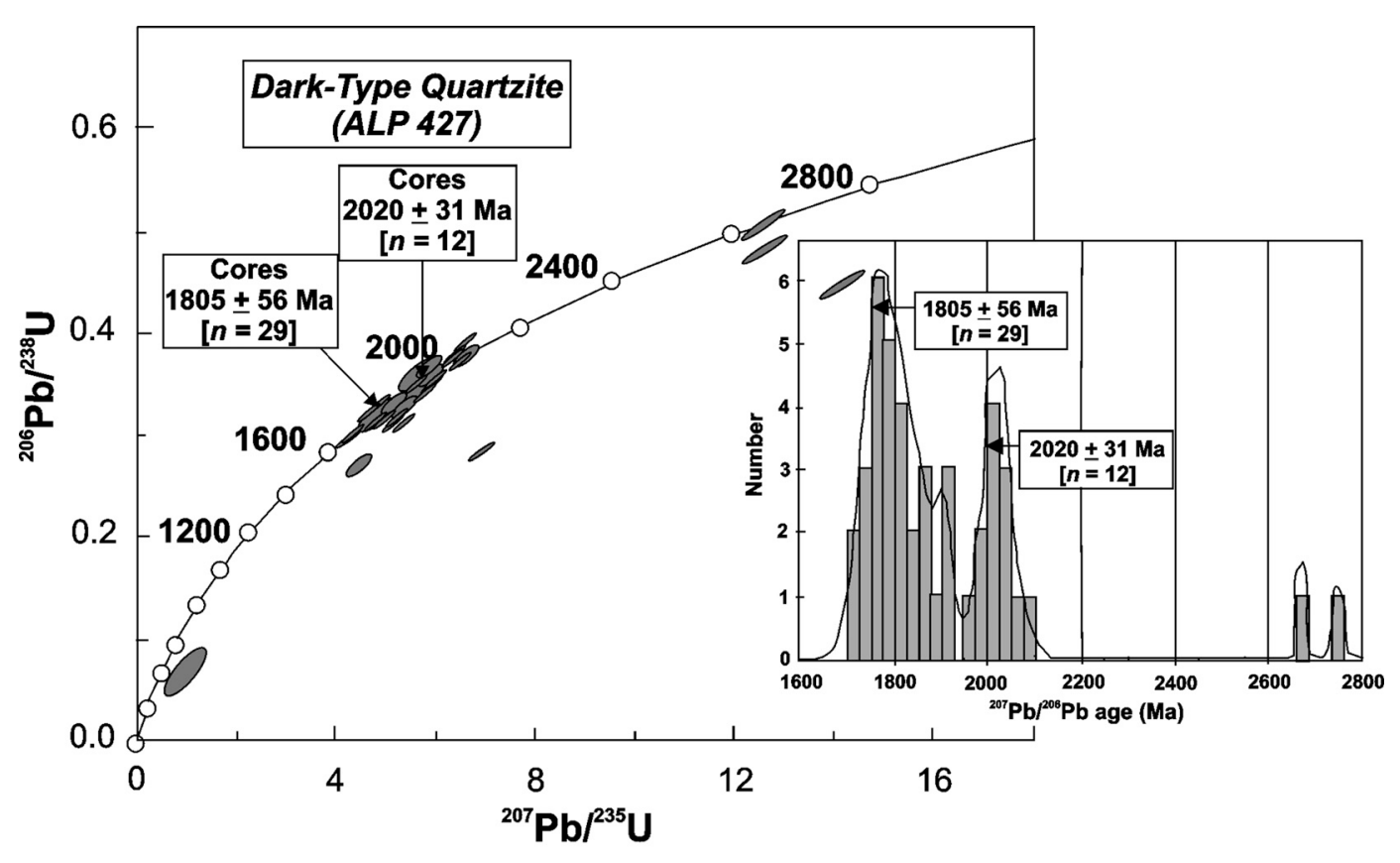

Figure 11. U-Pb concordia diagram for zircons from Dark-type Quartzite (sample ALP 427) from Namiesberg. The inset shows a histogram of ${ }^{207} \mathrm{~Pb} /{ }^{206} \mathrm{~Pb}$ ages for this sample. 

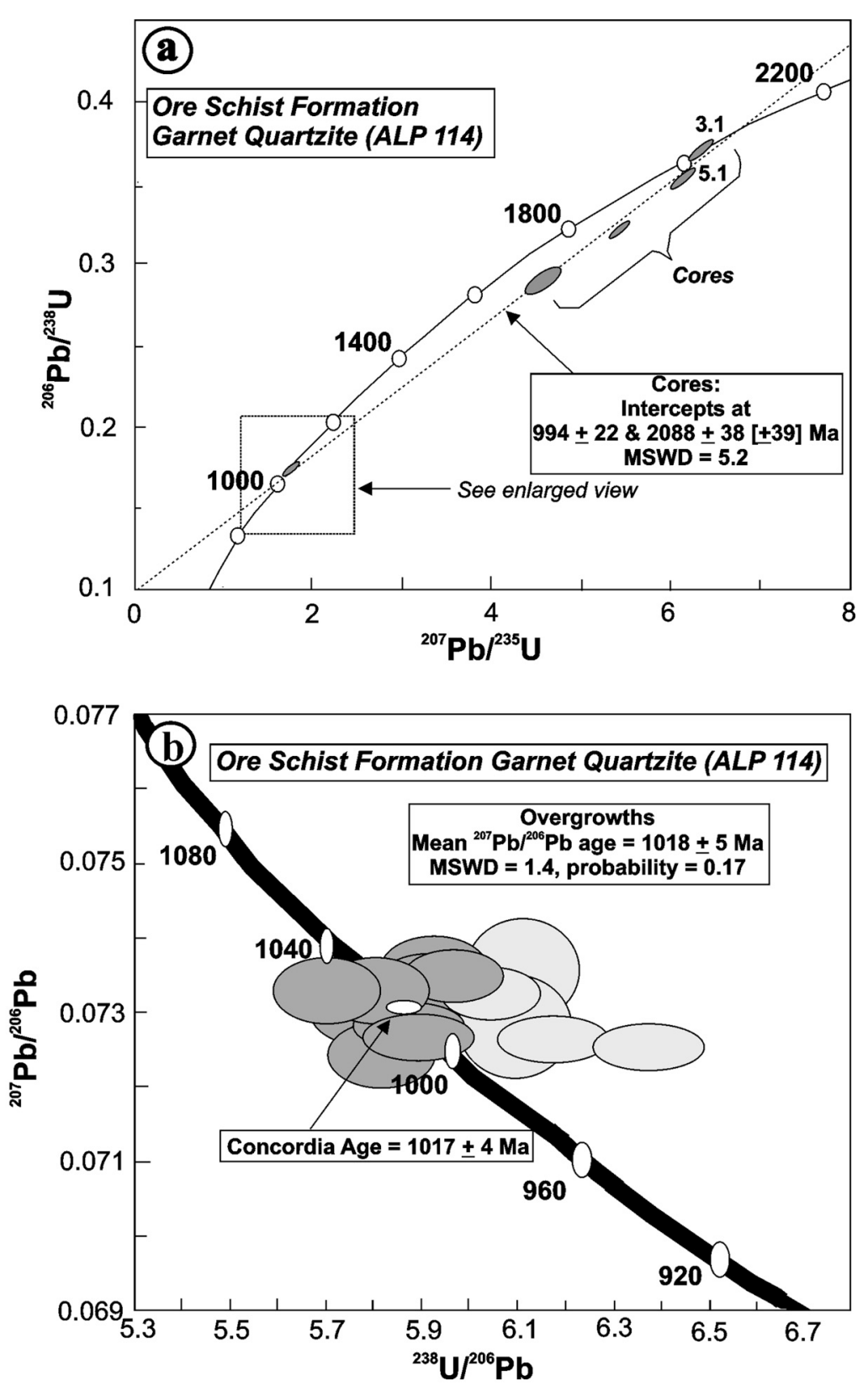

Figure 12. U-Pb concordia diagrams for zircons from the Ore Schist Formation Garnet Quartzite (sample ALP 114) from the Broken Hill Mine, Aggeneys. (a) shows the older ages of the cores with (b) showing the younger ages of the low $\mathrm{Th}$ and $\mathrm{Th} / \mathrm{U}$ overgrowths.

discordant (Figure 10). A single concordant age of 2872 $\pm 7 \mathrm{Ma}$ is also recorded (analysis 9.1 - Figures 8b and 10; Table A2).

A quartzite sample (ALP 427), collected by Lipson (1990) from Namiesberg to the east of Aggeneys (Figure 2), and tentatively correlated with the Dark Quartzite, here termed the Dark-type Quartzite, was also analysed for U-Pb geochronology. This sample was analysed by U-Pb single zircon dating during the 1980s, and has been re-analysed for this study. Detrital zircon ages are presented as a histogram and a U-Pb concordia plot in Figure 11, while selected analytical data of the more concordant analyses are listed in Table A3. There is a predominant grouping with an age of $1805 \pm 56 \mathrm{Ma}$
$(\mathrm{MSWD}=1.41)(n=29)$, and a smaller grouping with an age of $2020 \pm 31 \mathrm{Ma}(\mathrm{MSWD}=0.73)(n=12)$. This age distribution is similar to, and within error of that from the Dark Quartzite described above. Some highly discordant outlier zircon ages of greater than $\sim 2.5 \mathrm{Ga}$ also occur.

\section{Ore Schist Formation Garnet Quartzite}

Zircons were extracted from a garnet quartzite associated with the sulphide-rich iron formations of the Lower Ore Body at the Broken Hill Mine (Figure 3). The garnet quartzite (sample ALP 114) directly underlies a mineralised amphibole magnetite iron formation. Zircons from this lithology are large and euhedral, with 


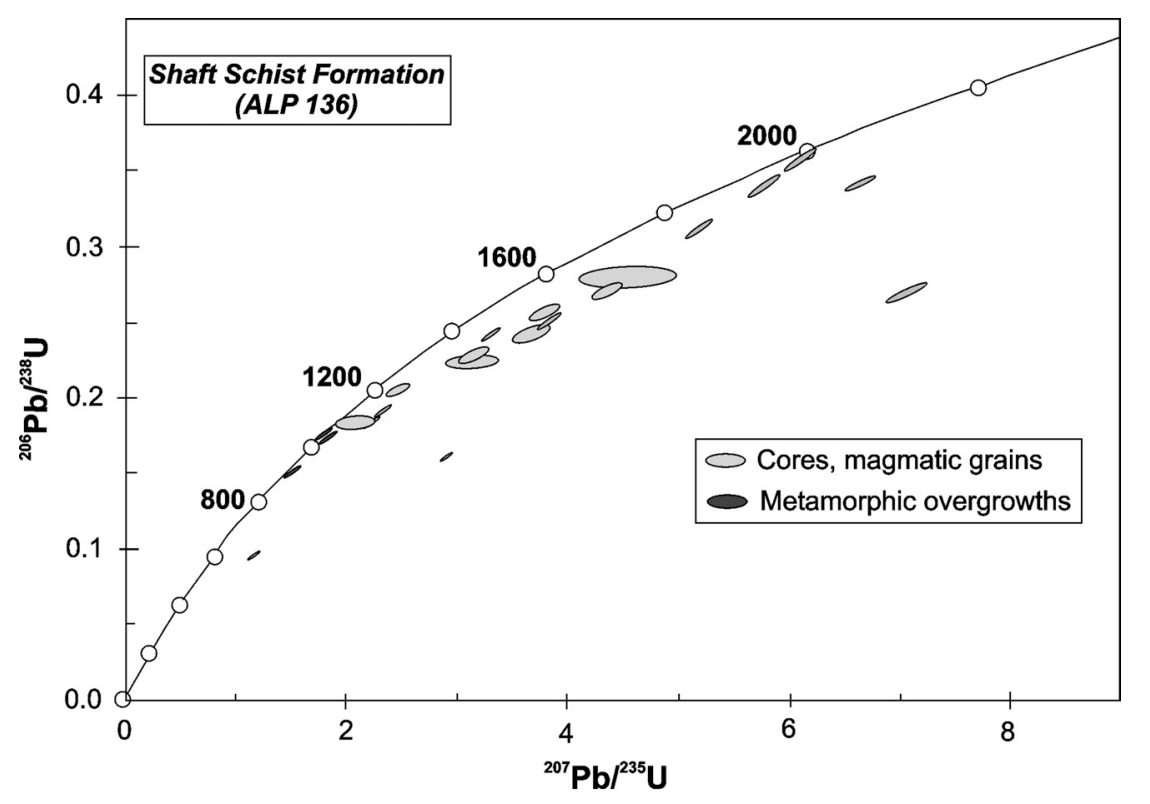

Figure 13. U-Pb concordia diagram for zircons from the Shaft Schist (sample ALP 136) from the Broken Hill Mine, Aggeneys.

weakly zoned concentric zonation in dark overgrowths, which have overgrown and resorbed bright, weakly zoned cores (Figure 8d). The zoning is commonly totally disturbed as a result of blurring and disruption with some grains having dark unzoned rims. The dark weakly zoned overgrowths are characterised by high $\mathrm{U}$ and low Th contents and low $\mathrm{Th} / \mathrm{U}$ ratios (Table A4). The bright zoned cores have low $\mathrm{U}$, but relatively high Th contents.
The host rock is characterised by very low Th and U contents of 0.2 and $1.2 \mathrm{ppm}$ respectively, with an exceptionally low $\mathrm{Th} / \mathrm{U}$ ratio of 0.2 .

On the U-Pb concordia plot (Figure 12), the bright cores of the zircons define a chord with an upper intercept of $2088 \pm 38 \mathrm{Ma}$ and a lower intercept of 994 $\pm 22 \mathrm{Ma}$. The bright cores have higher $\mathrm{Th} / \mathrm{U}$ ratios and, in general, give older ages of $\sim 2.0 \mathrm{Ga}$, representing

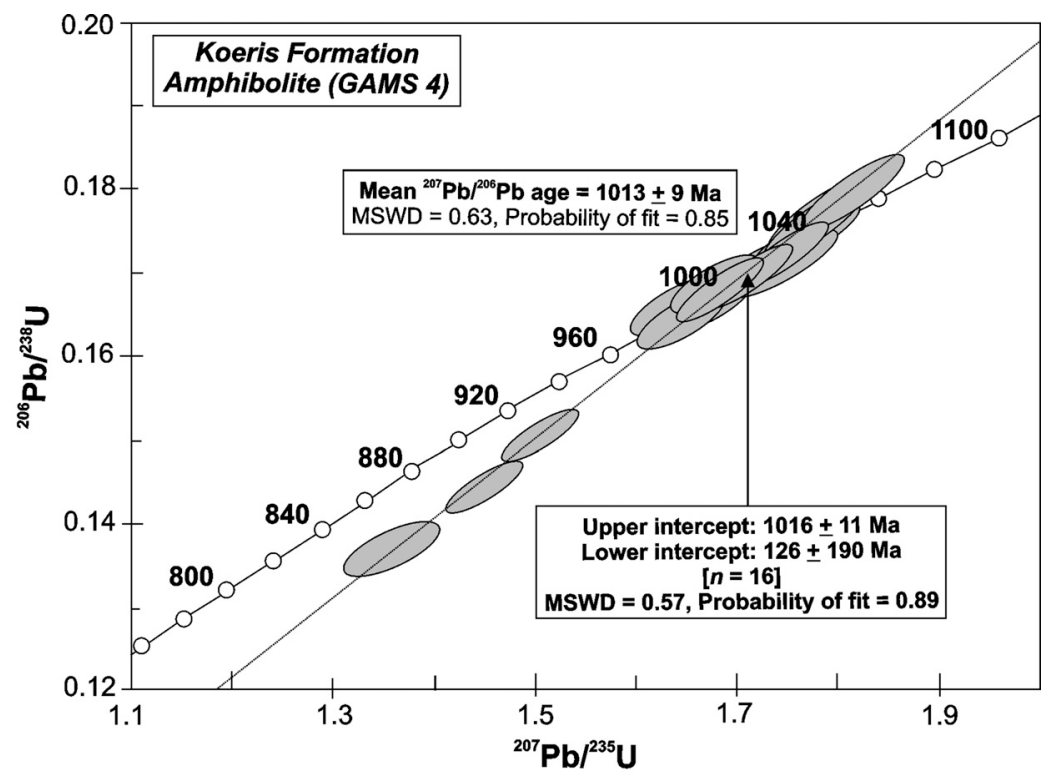

Figure 14. U-Pb concordia diagram for zircons from Koeris Formation amphibolite (sample Gams-4) from the Gamsberg inselberg. 
detrital ages. The dark, low Th/U overgrowths (Figures $8 \mathrm{~d}$ and 12), representing metamorphic overgrowths and rims, give a mean ${ }^{207} \mathrm{~Pb} /{ }^{206} \mathrm{~Pb}$ age of $1018 \pm 5 \mathrm{Ma}$ $($ MSWD $=1.4)$.

\section{Shaft Schist Formation}

A sample of Shaft Schist (ALP 136) used in the geochronological investigation came from borehole BH164 drilled at the Broken Hill Mine, Aggeneys. Only a few zircons were separated from this metapelite, and were mostly small, being between 50 and $90 \mathrm{~mm}$ in size, and metamictised to varying degrees. The zircons are characterised by bright, generally unzoned cores, which have been resorbed and overgrown by darker unzoned overgrowths and rims (Figure 8e).

Dark overgrowths or rims have high $U$ and low Th contents, and record younger ages of $\sim 1.15$ and $\sim 1.03 \mathrm{Ga}$ (Table A5). Bright unzoned cores have lower $\mathrm{U}$ and higher Th contents and have older ages. Most of the age data are very discordant, and seem to follow a discordia between an $\sim 2.0$ Ga source age and Pb-loss at $\sim 1.03 \mathrm{Ga}$ (Figure 13).

\section{Koeris Formation Amphibolite}

A sample of amphibolite from the Koeris Formation outcropping in the center of the basin-shaped Gamsberg inselberg, and with approximate co-ordinates $29^{\circ} 14^{\prime} 40$ "S and 18 $57^{\prime} 30^{\prime \prime}$ E (Figure 2), yielded a few zircons that have been analysed. The Koeris Formation unconformably overlies the Shaft Schist (Lipson, 1990) or Gams Iron Formation (Rozendaal, 1986; McClung et al., 2002) (Figure 3; Table 1) and cuts down into the Bushmanland Group to stratigraphic levels below that of the Namies Schist in some areas (McClung et al., 2002). A sample of the amphibolite was taken from this lithology, as Reid et al. (1987) obtained a Sm-Nd isochron age of $1649 \pm 90 \mathrm{Ma}$ from this lithology. The age of extrusion of the parent basalt would thus provide a constraint on the minimum age of deposition of the Bushmanland Group.

The amphibolite is comprised predominantly of dark green hornblende, plagioclase $\left(\mathrm{An}_{28-45}\right)$, interstitial quartz and accessory amounts of cordierite, magnetite and orthoclase. Zircon is present in accessory amounts, and reaches sizes of 50 to $150 \mu \mathrm{m}$. The zircons are subhedral and are sector zoned with zones of a uniform brightness (Figure 8f). Primary zonation is not preserved, nor do dark unzoned transgressive patches occur.

These zircons have similar low $\mathrm{Th} / \mathrm{U}$ chemistry as the garnet quartzite sample ALP 114 from the Broken Hill Mine and thus represent metamorphic zircon growth or recrystallisation. The Th and $\mathrm{U}$ contents of the zircons do not vary substantially (Table A6). The ages are also very similar (Figure 14) to those of the ore garnet quartzite from the Broken Hill Mine, giving an upper intercept age of $1016 \pm 11 \mathrm{Ma}(\mathrm{MSWD}=0.57$, prob. $=$ 0.89) and a mean ${ }^{207} \mathrm{~Pb} /{ }^{206} \mathrm{~Pb}$ age of $1013 \pm 9 \mathrm{Ma}$ (MSWD $=0.63$, prob. $=0.85$ ).

\section{Discussion \\ Geochemistry}

Extensive winnowing, reworking and deposition of the Bushmanland Group in a passive margin setting (Figure 5c) is indicated by both the extreme silica purity and clean, sheet-like nature of the quartzites (Lipson, 1990), as well as elevated alumina concentrations in the Namies and Schaft Schists. In addition, trace element ratios, such as $\mathrm{Zr} / \mathrm{Th}, \mathrm{Zr} / \mathrm{Sc}, \mathrm{Th} / \mathrm{Sc}, \mathrm{La} / \mathrm{Th}$ and $\mathrm{La} / \mathrm{Sc}$ (Figure $5 \mathrm{a}$ ), in excess of upper continental crustal values (Taylor and McLennan, 1985; McLennan et al., 2006), also indicate extensive reworking. This is supported by the Early Proterozoic to Archaean depleted mantle model ages of the metasediments (Figures 7c and d; Table 5), as Sm-Nd model ages of passive margin samples tend to be much older than those from active margins indicating older, presumably recycled, crustal sources (McLennan et al., 1990). Lipson (1990) and Hoffmann (1993) suggested that the extreme purity of the quartzites and the maturity of the metapelitic schists, along with a lack of a basaltic to andesitic provenance, argued for a cratonic interior provenance and deposition of the Bushmanland Group in a shallow siliciclastic sea environment with a constant rate of subsidence and / or provenance uplift, similar to that of the present-day Red Sea where active geothermal venting is depositing base metals in clayey muds accumulating in depressions on the sea floor (Bischoff, 1969).

The Namies Schist is more reworked and was derived from a more felsic feldspathic provenance than the Shaft or Shaft-type Schists due to the presence of positive Eu anomalies relative to NASC in these rocks (Figure 6c). It was deposited in an offshore shelf setting as shoreface sediments (Lipson, 1990). With relatively flat HREE patterns (Figure $6 \mathrm{c}$ ) and low $(\mathrm{Gd} / \mathrm{Yb})_{\mathrm{N}}$ ratios (Table 4), the Namies Schist and quartzites are likely to have been derived from K-rich granites (McLennan et al., 1990). The Shaft Schist, with higher $\mathrm{Cr}$ and lower $\mathrm{Zr}$ contents than the Namies Schist, is more biotite- and clay-rich and was deposited as lagoonal or estuarinal clay-rich black shales in a quiet, meromictic, anoxic reducing depositional environment (Lipson, 1990). This became less clay-rich higher up in the succession. Lipson (1990) argued that the Broken Hill Quartzite Formation represents the beach barrier, and the Ore Schist Formation largely represents a washover deposit comprising redistributed Namies Schist shoreface sediments. The smaller negative Eu anomaly (Figures $6 \mathrm{~b}$ and c) of the Namies Schist compared to the Shaft Schist also suggests that it was derived from a less weathered source than the latter as samples lacking negative Eu anomalies show little or no signs of weathering, whereas those with prominent negative Eu anomalies are derived from severely weathered sources (Taylor et al., 1986). Progradation and increasing degrees of reworking of the metasediments occurred toward the southeast (Lipson, 1990; Figure 4c), as seen in higher $\mathrm{Al}_{2} \mathrm{O}_{3}$ and $\mathrm{TiO}_{2}$ contents in the regional Namies- and Shaft-type Schists compared to the Namies Schist (Table 2). The Ore Schist 
Table 6. Summary of Sm-Nd and U-Pb single zircon SHRIMP ages for the Bushmanland Group of the Aggeneys District

\begin{tabular}{|c|c|c|c|c|c|c|}
\hline \multicolumn{7}{|l|}{ Sm-Nd } \\
\hline Lithology & & & $\mathbf{T}_{\text {CHUR }}(\mathrm{Ma})$ & $\mathbf{T}_{\mathrm{DM}}(\mathbf{M a})$ & $\begin{array}{c}\text { Text } \\
\text { figure }\end{array}$ & Table \\
\hline Bushmanland Group metasediments & & & $2485-1780$ & $2840-2250$ & 7 & 5 \\
\hline \multicolumn{7}{|l|}{ U-Pb single zircon SHRIMP ages } \\
\hline Rock type & $\begin{array}{l}\text { Sample } \\
\text { Number }\end{array}$ & $\begin{array}{c}\text { Inheritance } \\
T_{0}(\mathrm{Ma})\end{array}$ & $\begin{array}{c}M_{2} \\
T_{1}(\mathrm{Ma}) \\
\end{array}$ & $\begin{array}{c}M_{3} \\
T_{2}(\mathrm{Ma})\end{array}$ & $\begin{array}{c}\text { Text } \\
\text { figure }\end{array}$ & Table \\
\hline Namies Schist & ALP 39 & $1732 \pm 82$ & & & 9 & A1 \\
\hline Dark Quartzite & ALP 42 & $\begin{array}{l}2038 \pm 41 \\
1786 \pm 74\end{array}$ & $1171 \pm 31$ & $1040 \pm 30$ & 10 & A2 \\
\hline Dark-type Quartzite & ALP 427 & $\begin{array}{l}2020 \pm 31 \\
1805 \pm 56\end{array}$ & & & 11 & A3 \\
\hline Ore Garnet Quartzite & ALP 114 & $2088 \pm 38$ & & $1017 \pm 4$ & 12 & A4 \\
\hline Shaft Schist & ALP 136 & $\sim 2000$ & $1126 \pm 27^{\mathrm{a}}$ & $\sim 1030$ & 13 & A5 \\
\hline Amphibolite & Gams-4 & & & $1013 \pm 9$ & 14 & A6 \\
\hline
\end{tabular}

${ }^{a}$ Result based on one analysis

Formation metapelites have a predominantly clastic-dominated quartzofeldspathic nature dominated by clays (Lacassie et al., 2004), as seen by the positive correlation between $\mathrm{TiO}_{2}$ and $\mathrm{Al}_{2} \mathrm{O}_{3}$ in these metapelites (Figure 4d). A progression from a more quartzofeldspathic, felsic-dominated provenance, denoted by low Sc and high $\mathrm{Th} / \mathrm{Sc}$ ratios, to a more mafic-dominated provenance, with decrease in mineralogical maturity, occurs upwards in the stratigraphy (Figure 5b). The Namies Schist shows a progression from a less mature (or less reworked), $\mathrm{Al}_{2} \mathrm{O}_{3}$ - and $\mathrm{TiO}_{2}$-rich group with lower $\mathrm{SiO}_{2}$ contents to a more reworked $\mathrm{SiO}_{2}$-rich, $\mathrm{Al}_{2} \mathrm{O}_{3^{-}}$and $\mathrm{TiO}_{2}$-poor, quartzose fraction (Figure $4 \mathrm{a}$ and b) passing upwards into the White Quartzite, a feature also noted by Lacassie et al. (2006).

\section{Geochronology}

The Bushmanland Group metasediments predominantly record two detrital zircon age populations of $\sim 2.12$ to $\sim 1.97 \mathrm{Ga}$ and $\sim 1.88$ to $\sim 1.64 \mathrm{Ga}$ (Table 6 ). The presence of a few $>2.6 \mathrm{Ga}$ Archean grains may represent a very small Archean input, or be simply due to contamination during zircon separation and dating. Possible provenances of Paleoproterozoic age outcropping to the north, northwest and west, the sediment transport direction for the Bushmanland Group (Lipson, 1990), include the Richtersveld Subprovince and the gneisses of the Gladkop Suite around Steinkopf (Figure 1).

Rocks of the Richtersveld Subprovince form a composite calc-alkaline igneous province subdivided into two major components, the older extrusive Orange River Group (Reid, 1977), comprised of mafic and felsic lavas of $1996 \pm 15 \mathrm{Ma}$ age (Reid, 1979b), and the younger Vioolsdrif Intrusive Suite (Reid, 1979a; 1982), comprised of tonalites, granodiorites, adamellites, leucogranites and quartz-feldspar porphyries, of $1996 \pm$ $71 \mathrm{Ma}$ age (Sm-Nd isochron - Reid, 1997). Previously unpublished U-Pb SHRIMP zircon data for the Richtersveld Subprovince is given in Table A7. The rhyolites of the Orange River Group give a U-Pb upper intercept age of $1935 \pm 55 \mathrm{Ma}$ and a lower intercept age of $895 \pm 490 \mathrm{Ma}(\mathrm{MSWD}=2.2$ ). The large errors are due to a large amount of discordancy in the data. Younger ages of less than $1900 \mathrm{Ma}$ are obtained for the intrusion of the Vioolsdrif Intrusive Suite, with a

Table 7. Summary of age data for the possible provenance areas to the Bushmanland Group in the Namaqua Province.

\begin{tabular}{|c|c|c|c|c|c|c|c|}
\hline Lithology & $\begin{array}{l}\text { Rb-Sr } \\
\text { Age (Ma) }\end{array}$ & $\begin{array}{l}\text { Sm-Nd } \\
\text { age (Ma) }\end{array}$ & $\mathbf{T}_{\text {CHUR }}(\mathrm{Ma})$ & $\mathbf{T}_{\mathrm{DM}}(\mathbf{M a})$ & $\begin{array}{l}\text { Th-Pb } \\
\text { age (Ma) }\end{array}$ & $\begin{array}{l}\text { Pb-Pb } \\
\text { age (Ma) }\end{array}$ & $\begin{array}{l}\text { U-Pb zircon } \\
\text { age (Ma) }\end{array}$ \\
\hline Orange River Group & $\begin{array}{l}1957 \pm 54^{\mathrm{a}} \\
1927 \pm 905^{\mathrm{d}}\end{array}$ & $2085 \pm 89^{d}$ & 1900 to $2123^{\mathrm{c}}$ & 2094 to $2293^{c}$ & $1958 \pm 61^{\mathrm{a}}$ & $2067 \pm{ }_{86}^{80}$ & $\begin{array}{l}1875^{\mathrm{a}} \\
1996 \pm 15^{\mathrm{b}}\end{array}$ \\
\hline $\begin{array}{l}\text { Orange River Group - rhyolites } \\
\text { Vioolsdrif Intrusive Suite }\end{array}$ & $1676 \pm 42^{\mathrm{d}}$ & $1996 \pm 71^{\mathrm{c}}$ & 1765 to $2010^{\mathrm{c}}$ & 2116 to $2238^{c}$ & & & $1935 \pm 55^{\mathrm{f}}$ \\
\hline $\begin{array}{l}\text { Vioolsdrif Intrusive Suite - tonalite } \\
\text { Vioolsdrif Intrusive Suite - granite }\end{array}$ & $2014 \pm 142^{c}$ & & & & $1973 \pm 550^{\mathrm{d}}$ & $1839 \pm 58^{\mathrm{d}}$ & $1883 \pm 15^{\mathrm{f}}$ \\
\hline $\begin{array}{l}\text { Vioolsdrif Suite leucogranites } \\
\text { Gladkop Suite } \\
1822 \pm 36^{\mathrm{e}} \text { Brandewynsbank Gneiss }\end{array}$ & $1824 \pm 70^{\mathrm{d}}$ & & & & & $1770 \pm{ }^{+184} /$ & $\begin{array}{l}1870 \text { to } 1890^{\mathrm{f}} \\
190\end{array}$ \\
\hline $\begin{array}{l}\text { Steinkopf Gneiss } \\
\text { Noenoemaasberg Gneiss }\end{array}$ & $1806 \pm 102^{\mathrm{d}}$ & & & & & $1836 \pm{ }^{+202}$ & $218^{\mathrm{d}} \sim 2000^{\mathrm{d}}$ \\
\hline
\end{tabular}

${ }^{\mathrm{a}}$ Reid (1979a); ${ }^{\mathrm{b}}$ Reid (1979b); ${ }^{\mathrm{c}}$ Reid (1997); ${ }^{\mathrm{d}}$ Barton (1983); ${ }^{\mathrm{e}}$ Robb et al. (1999); ${ }^{\mathrm{f}}$ reported in this study. 
tonalite giving an upper intercept age of $1883 \pm 15 \mathrm{Ma}$ (MSWD $=1.8$ ), and the leucogranites giving a similar spread of ages between $\sim 1.89$ and $\sim 1.87 \mathrm{Ga}$. In general, the Richtersveld Subprovince predominantly gives ages of between $\sim 1.92$ and $\sim 1.86$ Ga (Table 6). Depleted mantle $\left(\mathrm{T}_{\mathrm{DM}}\right)$ Sm-Nd model ages of $\sim 2.29$ to $\sim 2.09$ Ga for the Orange River Group and $\sim 2.24$ to $\sim 2.12$ Ga for the Vioolsdrif Intrusive Suite (Reid, 1997; Table 7) are similar to, and slightly younger than those of the Bushmanland Group metasediments (Figure 7d; Table 5).

The grey-pink orthogneisses of the Gladkop Suite (Van Aswegen, 1983), to the west of Aggeneys (Figure 1), with a Rb-Sr age of $1824 \pm 70 \mathrm{Ma}$ (Barton, 1983) and a U-Pb zircon age of $1822 \pm 36 \mathrm{Ma}$ (Robb et al., 1999) (Table 7), may also have acted as provenance to the Bushmanland Group metasediments, as they have a similar age to the detrital zircon age population of the latter, as well as having appropriate compositions. Other provenance sources to the south, and possibly also to a far lesser extent to the east, may also have contributed detritus to the Bushmanland Group.

A break in sedimentation, marked by the unconformity recognised by McClung et al. (2002) at the base of the Broken Hill Quartzite Formation of the Kouboom Subgroup (the Dark Quartzite of Lipson, 1990; Figure 3; Table 1), is also recorded by not only changes in geochemical characteristics of the gneisses and quartzites, but also by detrital zircon ages and $\mathrm{Sm}-\mathrm{Nd}$ model ages (Figure 7; Tables 5 and 6). The Namies Schist of the Wortel Subgroup has a younger single detrital zircon population and younger Sm-Nd model ages than the metasediments of the overlying Kouboom Subgroup. The older $\sim 2.0 \mathrm{Ga}$ age population was not sourced prior to the erosional hiatus (Table 6), but begins to dominate upwards in the Kouboom Subgroup.

Work by Reid et al. (1987) led them to suggest an age of sediment deposition of between $\sim 2.0$ and $\sim 1.65 \mathrm{Ga}$. The detrital zircon ages obtained in this study, however, suggest a younger depositional age for the Bushmanland Group. No major tectonic, magmatic or metamorphic events appear to have been recorded between $\sim 1.64 \mathrm{Ga}$ (the age of the youngest detrital zircon in the Namies Schist, analysis 2.1 , Table A1) and $\sim 1.2$ Ga so that this period is a likely time for deposition of the Bushmanland Group and associated mineralisation at Aggeneys (Figure 15). Raith et al. (2003) reported ages for detrital zircons from the tectono-stratigraphic lowermost part of the Kamiesberg Subgroup around the Bitterfontein area in the southwestern Namaqua Province of between $\sim 1.25$ and $\sim 1.2 \mathrm{Ga}$ and an age of deposition prior to a tectonothermal event at $\sim 1.19 \mathrm{Ga}$. Thus an age of deposition of $\sim 1.2 \mathrm{Ga}$ for the Bushmanland Group is also feasible.

The Aggeneys - Gamsberg BHT deposits differ from typical BHT deposits in that, based on the detrital zircon ages obtained in this study, they are younger than other BHT deposits, such as the Broken Hill Main Lode, New South Wales, Cannington, Queensland, Australia and the
Zinkgruvan deposit in Sweden, all of which are of Paleoproterozoic age (Parr and Plimer, 1993; Walters, 1996). The Bushmanland Group deposits also seemingly differ from other BHT deposits (Parr and Plimer, 1993; Walters, 1996) in having clean, highly mature quartzites, a passive margin setting and the absence of evaporitic lithologies in the near ore and footwall sequences.

The voluminous pink and grey granitic gneisses, including the Achab and Hoogoor Gneisses, which occur throughout the region (Figure 1) and act as present day basement to the supracrustal succession, have been cited as provenance, basement and possible source of base metals to the metasediments by previous workers (Duncan et al., 1984, 1985; Moore et al., 1990; Reid et al., 1997b). However, these gneisses are dominated by $\sim 1.21$ to $\sim 1.17$ Ga magmatic zircon U-Pb ages (Bailie et al., 2005). No detrital zircons of this age are recorded in the Bushmanland Group (Table 6), so that these granitic gneisses could not have acted as provenance, basement or source of base metals to the Bushmanland Group metasedimentary succession, but are rather intrusive into the supracrustal succession.

The Bushmanland Group metasediments at Aggeneys show similar parageneses, detrital zircon and Sm-Nd model age distributions to that of the Khurisberg Subgroup of the Okiep District (Clifford et al., 1981; 2004; Figure 15), a possible correlative of the Bushmanland Group in the Aggeneys area (Clifford et al., 1981, Joubert, 1986). Barton (1983) and Robb et al. (1999) have argued, however, that the Khurisberg Subgroup pre-dates the intrusion of the $c a$. 1820 Ma old granitic rocks of the Gladkop Suite. As such, the granitic rocks of the Gladkop Suite, occurring in the eastern part of the Ratelpoort Synform north of Springbok (Figure 1), still need to be accurately dated in order to firmly establish a minimum age for the Khurisberg Subgroup (Clifford et al., 2004).

The detrital zircons of the Bushmanland Group in the Aggeneys District have been subjected to two discrete periods of new metamorphic zircon growth, present as low $\mathrm{Th} / \mathrm{U}$ overgrowths and rims. Metamorphic growth may be distinguished from magmatic growth in zircons by high $\mathrm{U}$ and low Th contents, low $\mathrm{Th} / \mathrm{U}$ ratios, and diffuse weakly zoned areas or dark unzoned patches, rims, overgrowths and embayments (Connelly, 2000).

The Kibaran Orogeny $(\sim 1.22$ to $\sim 1.17 \mathrm{Ga})$ represents a major tectono-thermal event, corresponding to the collision of the Namaqua Province with the Kaapvaal Craton (Hartnady et al., 1985; Thomas et al., 1993a; Jacobs et al., 1993; Jacobs and Thomas, 1994). In the Aggeneys District this episode was dominated by magmatism due to extensive crustal reworking, partial melting and granitic magmatism in the form of the Aggeneys Granite Suite (Bailie et al., 2005), accompanied by the regionally significant $D_{2}$ deformation and peak upper amphibolite facies grade $M_{2}$ metamorphism which correlates with a similar period 


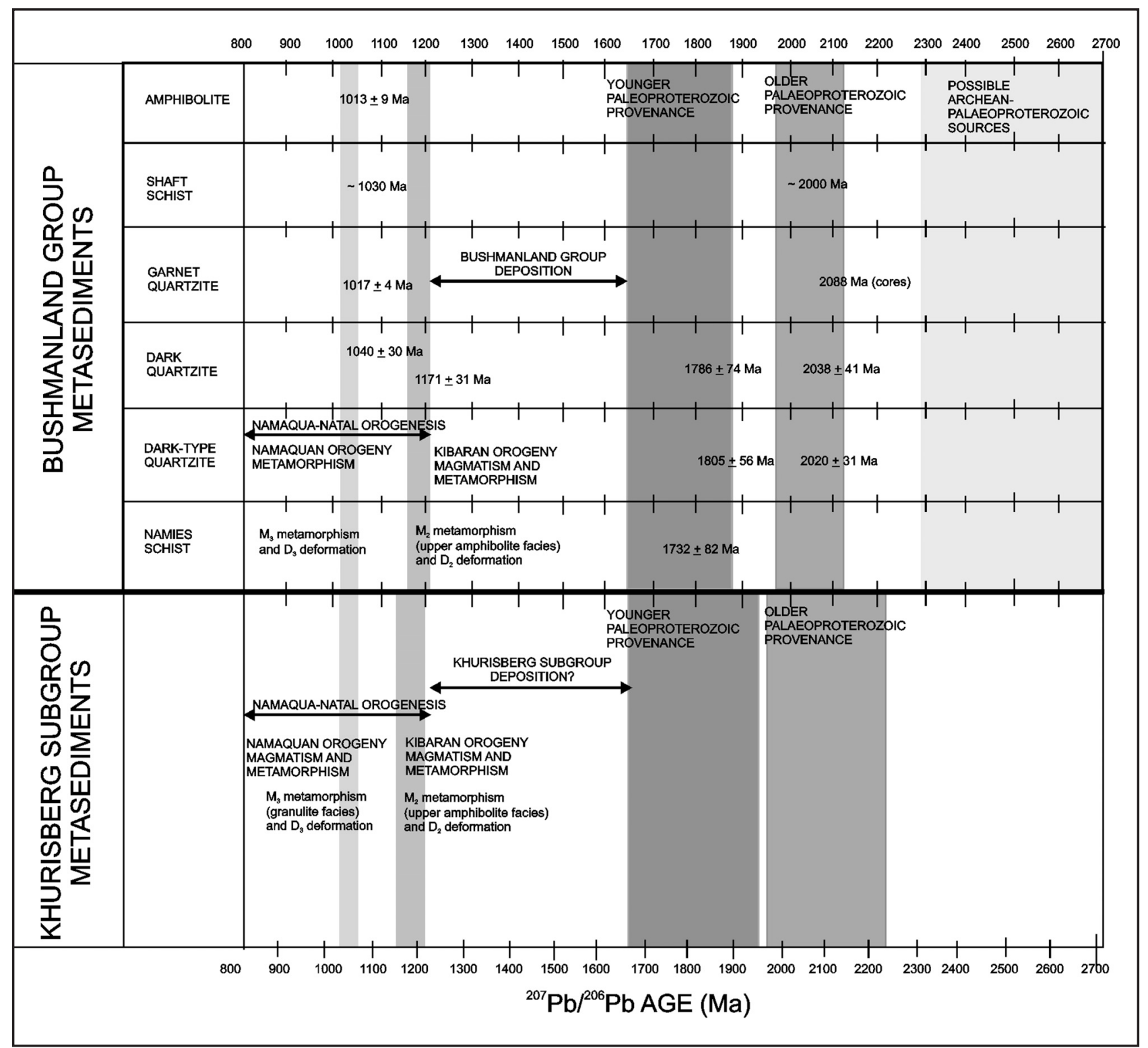

Figure 15. Comparison of geochronology for Bushmanland Group metasediments of the Aggeneys District and the metasediments of the Khurisberg Subgroup, Okiep District, Namaqualand to the west (from data in Clifford et al., 2004).

of extensive magmatism and amphiolite facies metamorphism in the Okiep District in Namaqualand to the west (Robb et al., 1999; Clifford et al., 2004; Figure 15) and deposition of the Kamiesberg Subgroup in the southern Namaqua Province (Raith et al., 2003). A similar period of tectono-magmatism occurred in the Natal Province in the east (McCourt et al., 2006; Eglington, 2006). This episode is not extensively recorded as metamorphic overgrowths or rims in the metasediments, with only the Dark Quartzite (ALP 42; Figure 10; Tables 6 and A2) having numerous low Th/U overgrowths and rims of $1171 \pm 31 \mathrm{Ma}$ age. This age corresponds well with a weighted mean ${ }^{207} \mathrm{~Pb} /{ }^{206} \mathrm{~Pb}$ age of $1175 \pm 23 \mathrm{Ma}$ for this tectono-magmatic episode for zircons from a cordierite-hypersthene paragneiss from the Okiep District (Clifford et al., 2004). Kibaran Orogeny metamorphism and deformation caused remobilisation and recrystallisation of the Aggeneys massive sulphide ores (Joubert, 1986), such as into the hinge zones of $F_{2}$ folds. By $\sim 1.17$ Ga $M_{2}$ metamorphism started waning and a period of tectonic quiescence started.

Subsequently, after a period of $\sim 140$ Ma of tectonic quiescence, tectonism, magmatism and metamorphism accompanied deformation during the Namaquan Orogeny $(\sim 1.06$ to $\sim 1.01 \mathrm{Ga})$, particularly to the west in Namaqualand in the Okiep District (Robb et al., 1999; Clifford et al., 2004; Andreoli et al., 2006; Eglington, 2006) (Figure 15). There is no evidence to suggest a magmatic or metamorphic event in the Aggeneys District between $\sim 1.17$ and $\sim 1.04 \mathrm{Ga}$. Similar periods of crustal growth and metamorphism of between $\sim 1.21$ and $\sim 1.16 \mathrm{Ga}$ and $\sim 1.07$ and $\sim 1.03 \mathrm{Ga}$ are recorded by Thomas et al. (1993b; c), Eglington (2006) and McCourt et al. (2006) for granites and granitic gneisses in the Natal Province on the east coast of South Africa. 
No magmatism is recorded in the Aggeneys District during the Namaquan Orogeny. Rather this area was affected by deformation $\left(D_{3}\right)$ and metamorphism $\left(M_{3}\right)$, as recorded by dark, unzoned overgrowths and rims on detrital zircons having low $\mathrm{Th} / \mathrm{U}$ ratios (Table 6). Extensive fluid flow along lithological contacts (e.g. sample ALP 114) may have occurred at this time. $M_{3}$ metamorphism in the Aggeneys District occurred at $\sim 1.02$ to $1.01 \mathrm{Ga}$, the age of low $\mathrm{Th} / \mathrm{U}$ metamorphic overgrowths in zircons from the ore garnet quartzite (Figure 12; Table A4) and Koeris Formation amphibolite (Figure 14; Table A6). The lowermost Wortel Subgroup of the Bushmanland Group shows minimal effects of Namaquan Orogeny metamorphism.

The Kalahari-Grunehogna Craton could have lain to the southwest of Laurentia with the Namaqua-Natal Belt facing outboard and away from the Laurentian Craton (Powell et al., 2001). Pisarevsky et al. (2003) suggest that the Kalahari Craton could have lain off the western margin of Australia until $\sim 800$ to $\sim 750 \mathrm{Ma}$. These authors proposed that the Kalahari-Dronning Maud Land Craton joined the Australia-Mawson Craton during oblique collision between $\sim 1.1$ and $\sim 1.0 \mathrm{Ga}$. Metamorphism in both Dronning Maud Land and the Darling Mobile Belt occurred at $\sim 1.08$ to $\sim 1.05 \mathrm{Ga}$ (Jacobs et al., 1998) and metasediments in both belts have indistinguishable detrital zircon populations (Pisarevsky et al., 2003 and references therein). Pisarevsky et al. (2003) also noted that, with this model, paleopoles from the Kalahari Craton converge with the Laurentian apparent polar wander path (APWP) between $\sim 1.07$ and $\sim 1.0 \mathrm{Ga}$. The collision of the Bushmanland Subprovince, with the co-joined Richtersveld Subprovince, with the Kakamas Terrane at $\sim 1.2 \mathrm{Ga}$, which caused upper amphibolite $M_{2}$ metamorphism, thus forms a precursor to the amalgamation of the Kalahari-Dronning Maud Land Craton with the Australia-Mawson Craton during Mesoproterozoic times. The subsequent metamorphism at $\sim 1.04$ to $\sim 1.01 \mathrm{Ga}$, which was accompanied by granulite grade metamorphism in the Okiep District in Namaqualand to the west, was associated with convergence and collision of the Kalahari Craton with Laurentia during Rodinia construction.

\section{Summary}

The Bushmanland Group metasediments in the Aggeneys District were derived from old upper continental crust, likely to have been a moderately weathered provenance comprised of granodiorites, tonalites and granites, and their extrusive equivalents. Mixed sources are likely from the geochemical signatures of the metasediments. The metapelitic schists were derived from illite-and smectite-bearing mudstones that had not advanced to the kaolinite stage (Lipson, 1990; Hoffmann, 1993; Figure 4e). A degree of extensive winnowing and reworking of the sediments also likely occurred prior to, or just after deposition (Figure 5a), suggesting a cratonic interior provenance with a passive margin setting. All the metasediments exhibit
K-enrichment and Na-depletion relative to average shale or arkose compositions (Figure 4f).

The fundamental chemical and mineralogical differences between the basal Namies and upper Shaft Schists may have resulted from erosion of different provenances (Lipson, 1990), where a difference in detrital zircon ages and Sm-Nd model ages is also noted between the two (Table 6). The Namies Schist, with a greater feldspathic character and compositional range, was derived from a slightly more quartzofeldspathic provenance than the Shaft Schist, which was, in turn derived from a more plagioclase- and quartz-poor provenance and had a clay-dominated precursor. An increasingly greater mafic component to the provenance is present with height in the stratigraphy.

Detrital zircons in the Bushmanland Group predominantly record two age populations of $\sim 2.12$ to $\sim 1.97 \mathrm{Ga}$ and $\sim 1.88$ to $\sim 1.64 \mathrm{Ga}$ (Table 6 ), so that at least two distinct provenances fed the Bushmanland Group basin in this area. The metasediments of the older Wortel Subgroup predominantly sourced the younger provenance, whereas the overlying Kouboom Subgroup sourced both. Depleted mantle $\left(\mathrm{T}_{\mathrm{DM}}\right) \mathrm{Sm}-\mathrm{Nd}$ model ages of $\sim 2.85$ to $\sim 2.25$ Ga (Figure 7e; Tables 5 and 6) reflect derivation from old, recycled crustal sources. Possible provenances include the $\sim 2.1$ to $\sim 1.85$ Ga magmatic rocks of the Richtersveld Subprovince to the northwest (Reid, 1977; 1979a; b, 1982; 1997) (Tables 6 and A7), as well as the granitic orthogneisses of the Gladkop Suite (Van Aswegen, 1983), to the west of the Aggeneys District (Figure 1), having $\sim 1.84$ to $\sim 1.82 \mathrm{Ga}$ ages. Other possible provenances may have been to the south as well as to the north and east. Bushmanland Group deposition is taken to have occurred between $\sim 1.64 \mathrm{Ga}$ (the youngest detrital zircon) and $\sim 1.21 \mathrm{Ga}$, the onset of the Kibaran Orogeny in the Aggeneys District (Figure 15), making it younger than other BHT deposits. The Bushmanland Group shows a similar age distribution of detrital zircons and Sm-Nd model ages as the Khurisberg Subgroup in the Okiep District to the west (Clifford et al., 2004) (Figure 15), with which it may possibly be correlated.

The tectono-magmatic Kibaran Orogeny ( 1.21 to $\sim 1.17 \mathrm{Ga}$ ), which is marked by extensive magmatism (the Little Namaqualand Suite), peak $D_{2}$ deformation and $M_{2}$ upper amphibolite facies grade metamorphism, is not preferentially recorded as metamorphic overgrowths and rims in the Bushmanland Group metasediments. The timing of $M_{2}$ metamorphism in the Aggeneys District is taken as $\sim 1.17 \mathrm{Ga}$ from metamorphic overgrowths on a Dark Quartzite sample. The $\sim 1.04$ to $\sim 1.01$ Ga Namaquan Orogeny, marked by $M_{3}$ metamorphism and $D_{3}$ deformation, is recorded by metamorphic overgrowths and rims on detrital zircons of predominantly $\sim 1.02$ to $1.01 \mathrm{Ga}$ ages.

\section{Acknowledgements}

Financial support from the National Research Foundation and its several predecessors, the University 
of Cape Town, along with past and current holding companies of the Aggeneys ore district (Goldfields of South Africa, O'okiep Copper Company, AngloAmerican) is gratefully acknowledged. Protracted discussion on most aspects of Namaqualand geology with John Moore, Pieter Joubert, Rael Lipson, Hennie Blignault, Aylva Schoch, Wayne Colliston, Craig McClung, and numerous others are greatly appreciated. Jens Gutzmer is thanked for his useful and helpful reviews of an earlier version of this manuscript. Jan Kramers and Bob Thomas are thanked for helpful and constructive reviews of this manuscript. This paper is dedicated to deceased colleagues and mentors: Tony Erlank, Hugh Allsopp, Hans Welke, Peter Betton and Oom Jan Marais.

\section{References}

Andreoli, M.A.G., Hart, R.J., Ashwal, L.D. and Coetzee, H. (2006). Correlations between $\mathrm{U}$, Th content and metamorphic grade in the western Namaqualand Belt, South Africa, with implications for radioactive heating of the crust. Journal of Petrology, 47, 1095-1118.

Armstrong, R.A., Reid, D.L., Watkeys, M.K., Welke, H.J., Lipson, R.D. and Compston, W. (1988). Zircon U-Pb ages from the Aggeneys area, central Bushmanland. Extended Abstract Geocongress '88, Durban, Geological Society of South Africa, 493-496.

Bailie, R. H., Armstrong, R. A. and Reid, D. L. (2005). Age and composition of the granitic gneisses of the Aggeneys District, Namaqua Province, South Africa, Abstract, GEO2005 Geological Society of South Africa, 6.

Barton, E.S. (1983). Reconnaissance isotopic investigations in the Namaqua mobile belt and implications for Proterozoic crustal evolution Namaqualand geotraverse. Special Publication of the Geological Society of South Africa, 10, 45-66.

Beeson, R. (1990). Broken Hill-type lead-zinc deposits - an overview of their occurrence and geological setting. Transactions of the Institution of Mining and Metallurgy (Section B), 99, 163-175.

Bhatia, M.R. (1983). Plate tectonics and geochemical composition of sandstones. Journal of Geology, 91, 611-627.

Bhatia, M.R. and Crook, K.W. (1986). Trace element characteristics of greywackes and tectonic discrimination of sedimentary basins. Contributions to Mineralogy and Petrology, 92, 181-193.

Bischoff, J.L. (1969). Red Sea geothermal brine deposits: their mineralogy, geochemistry and genesis. In: Degens, E.T. and Ross, D.A. (Editors) Hot Brines and Recent Heavy Metal Deposits in the Red Sea. Springer-Verlag, Berlin, Germany, 368-401.

Blignault, H.J., Van Aswegen, G., Van der Merwe, S.W. and Colliston, W.P. (1983). The Namaqualand Geotraverse and environs: part of the Proterozoic mobile belt. Special Publication of the Geological Society of South Africa 10, 1-29.

Bock, B., McLennan, S.M. and Hanson, G.N. (1994). Rare earth element redistribution and its effects on the neodymium isotope system in the Austin Glen Member of the Normanskill Formation, New York, United States of America. Geochimica et Cosmochimica Acta, 58, 5245-5253.

Boynton, W.V. (1984). Geochemistry of the rare earth elements: meteorite studies. In: P. Henderson (Editor), Rare earth element geochemistry. Elsevier, Amsterdam, The Netherlands, 63-114

Clifford, T.N., Gronow, J., Rex, D.C. and Burger, A.J. (1975). Geochronological and petrogenetic studies of high-grade metamorphic rocks and intrusives in Namaqualand, South Africa. Journal of Petrology, 16, 154-188

Clifford, T.N., Stumpfl, E.F., Burger, A.J., McCarthy, T.S. and Rex, D.C. (1981) Mineral-chemical and isotopic studies of Namaqualand granulites, South Africa: A Grenville analogue. Contributions to Mineralogy and Petrology, 77, 225-250

Clifford, T.N., Barton, E.S., Retief, E.A., Rex, D.C. and Fanning, C.M. (1995). A crustal progenitor for the intrusive anorthosite - charnockite kindred of the cupriferous Koperberg Suite, O'okiep district, Namaqualand, South Africa: New isotope data for the country rocks and intrusives. Journal of
Petrology, 36, 231-258.

Clifford, T.N., Barton, E.S., Stern, R.A. and Duschene, J.-C. (2004). U-Pb zircon calendar for Namaquan (Grenville) crustal events in the granulitefacies terrane of the O'okiep Copper District of South Africa. Journal of Petrology, 45, 669-691.

Colliston, W.P., Praekelt, H.E., Strydom, D. and Pretorius, J.J. (1986). Stratigraphic map of Central Bushmanland (1: 100000 geological map). Department of Geology, University of the Orange Free State, Bloemfontein. 1 sheet.

Colliston, W.P., Praekelt, H.E. and Schoch, A.E. (1989). A broad perspective (Haramoep) of geological relations established by sequence mapping in the Proterozoic Aggeneys terrane, Bushmanland, South Africa. South African Journal of Geology, 92, 42-48.

Colliston, W.P., Praekelt, H.E. and Schoch, A.E. (1991). A progressive shear model for the Proterozoic Aggeneys Terrane, Namaqua mobile belt, South Africa. Precambrian Research, 49, 205-215.

Colliston, W.P. and Schoch, A.E. (1998). Tectonostratigraphic features along the Orange River in the western part of Mesoproterozoic Namaqua mobile belt. South African Journal of Geology, 101, 91-100.

Colliston, W.P. and Schoch, A.E. (2003). A mid-Proterozoic volcanosedimentary sequence in the Aggeneys Hills Duplex, Namaqua Metamorphic Complex. South African Journal of Geology, 106, 343-360.

Compston, W., Williams, I.S. and Meyer, C. (1984). U-Pb geochronology of zircons from Lunar Breccia 73217 using a sensitive high mass-resolution ion microprobe. Journal of Geophysical Research, 89, B525-B534.

Connelly, J.N. (2000). Degree of preservation of igneous zonation in zircon as a signpost for concordancy in $\mathrm{U} / \mathrm{Pb}$ geochronology. Chemical Geology, 172, 25-39.

Condie, K.C. and Wronkiewicz, D.S. (1990). The Ce/Th ratio in Precambrian pelites from the Kaapvaal Craton as an index of cratonic evolution. Earth and Planetary Science Letters, 97, 256-267.

DePaolo, D.J., Linn, A.M. and Schubert, G. (1991). The continental crustal age distribution: Methods of determining mantle separation ages from Sm$\mathrm{Nd}$ isotopic data and application to the southwestern United States. Journal of Geophysical Research, 96 B2, 2071-2088.

Duncan, A.R., Watkeys, M.K. and Moore, J.M. (1984). Geochemistry of the "floor" rocks of Namaqualand. Abstrtacts, Mid-late Proterozoic Crustal Evolution Symposium, University of Cape Town, South Africa, 75-76.

Duncan, A.R., Joubert, P., Reid, A.M., Watkeys, M.K., Betton, P.J., Reid, D.L., Erlank, A.J. and Cleverly, R.W. (1985). Geochemical studies on the floor rocks of Namaqualand. Unpublished Final Report, National Geoscience Programme, Council For Scientific And Industrial Research, South Africa, 173pp.

Eglington, B.M. (2006). Evolution of the Namaqua-Natal Belt, southern Africa - A geochronological and isotope geochemical review. Journal of African Earth Sciences, 46, 93-111.

Frimmel, H.E., Hoffmann, D. and Moore, J.M. (1993). Preservation of syndepositional geochemical characteristics of the Broken Hill massive sulphide deposits, South Africa, during upper amphibolite facies metamorphism. In: Fenoll, H.-A., Torres-Ruiz, Gervilla, F. (Editors), Current Research in Geology Applied to Ore Deposits, ISBN, 303-306.

Geological Staff Black Mountain (1996). The base metal deposits of Aggeneys, Northern Cape. Anglo American Operations Limited Internal Report, 20pp.

Gromet, L.P., Dymek, R.F., Haskin, L.A. and Korotev, R.L. (1984). The "North American Shale Composite": its compilation, major and trace element characteristics. Geochimica et Cosmochimica Acta, 48, 2469-2482.

Hartnady, C., Joubert, P. and Stowe, C. (1985). Proterozoic crustal evolution in south-western Africa. Episodes, 8, 236-244.

Hawkesworth, C.J. and van Calsteren, P.W.C. (1984). Radiogenic isotopes some geological applications. In: P. Henderson, Rare earth element geochemistry. Elsevier, Amsterdam, The Netherlands, 375-421.

Hoffman PF (1991) Did the breakout of Laurentia turn Gondwana inside out? Science, 252, 1409-1412

Hoffmann, D. (1993). Aspects of the geology, geochemistry and metamorphism of the lower orebody, Broken Hill deposit, Aggeneys. Unpublished MSc thesis, University of Cape Town, South Africa, 211pp.

Jacobs, J., Thomas, R.J. and Weber, K. (1993). Accretion and indentation tectonics at the southern edge of the Kaapvaal craton during the Kibaran (Grenville) orogeny. Geology, 21, 203-206.

Jacobs, J. and Thomas, R.J. (1994). Oblique collision at about $1.1 \mathrm{Ga}$ along 
the southern margin of the Kaapvaal continent, southeast Africa. Geologische Rundschau, 83, 322-333.

Jacobs, J., Fanning, C.M., Henjes-Kunst, F., Olesch, M., Paech, H.-J. (1998) Continuation of the Mozambique Belt into East Antarctica: Grenville-age metamorphism and polyphase Pan-African high-grade events in Central Dronning Maud Land. Journal of Geology, 106, 385-406.

Jacobsen, S.B. and Wasserburg, G.J. (1980). Sm-Nd isotopic evolution of chondrites. Earth and Planetary Science Letters, 50, 139-155.

Joubert, P. (1974). The gneisses of Namaqualand and their deformation. Transactions of the Geological Society of South Africa, 77, 339-346.

Joubert, P. (1986). The Namaqualand Metamorphic Complex - a summary. In: C. R. Anhaeusser and S.Maske (Editors), Mineral Deposits of Southern Africa, Geological Society of South Africa, 1395-1420.

Lacassie, J.P., Roser, B.P., Ruiz del Solar, J. and Hervé, F. (2004). Visualization of geochemical datasets by using neural networks: a novel perspective for sedimentary provenance analysis. Sedimentary Geology, 165, 175-191.

Lacassie, J.P., McClung, C.R., Bailie, R.H., Gutzmer, J. and Ruiz-del-Solar, J (2006). Geochemical patterns of schists from the Bushmanland Group: An artificial neural networks approach. Journal of Geochemical Exploration, 91, 81-98.

Lipson, R.D. (1978). Some aspects of the geology of part of the Aggeneysberge and surrounding gneisses, Namaqualand. Unpublished MSC thesis, University of the Witwatersrand, Johannesburg, South Africa, 100pp.

Lipson, R.D. (1990). Lithogeochemistry and origin of metasediments hosting the Broken Hill Deposit, Aggeneys, South Africa, and implications for ore genesis. Unpublished PhD thesis, University of Cape Town, South Africa. 245pp.

Lipson, R.D., Martin, G.J. and Hobbs, J.B.M. (1986). Heavy mineral layers: evidence of a clastic origin for Bushmanland quartzite genesis at Aggeneys. Transactions of the Geological Society of South Africa, 89, 367-372.

Ludwig, K.R. (2001). Isoplot / Ex (version 2.49). A geochronological toolkit for Microsoft Excel. Berkeley Geochronology Center, Special Publication 1a. McClung, C.R. (2006). Basin analysis of the Bushmanland Basin, Namaqualand Metamorphic Complex, Northern Cape Province, South Africa. Unpublished PhD thesis, University of Johannesburg, South Africa, 320pp.

McClung, C.R., Beukes, N. and Gutzmer, J. (2002). Basin analysis of the Bushmanland Basin, western Namaqualand Metamorphic Complex, Northern Cape Province, South Africa. Progress Report, Department of Geology, Rand Afrikaans University (RAU), Johannesburg, South Africa, $31 \mathrm{pp}$.

McCourt, S., Armstrong, R.A., Grantham, G.H., Thomas, R.J. (2006). Geology and evolution of the Natal belt, South Africa. Journal of African Earth Sciences, 46, 71-92

McLennan, S.M. (1989). Rare earth elements in sedimentary rocks: influence of provenance and sedimentary processes. In: B. R. Lipin and G. A. McKay (Editors), Geochemistry and mineralogy of rare earth elements. Reviews in Mineralogy, 21, 169-200.

McLennan, S.M., Taylor, S.R., McCulloch, M.T. and Maynard, J.B. (1990). Geochemical and Nd-Sr isotopic composition of deep-sea turbidites: crustal evolution and plate tectonic associations. Geochimica et Cosmochimica Acta, 54, 2015-2050.

McLennan, S.M. and Taylor, S.R. (1991). Sedimentary rocks and crustal evolution revisited: tectonic setting and secular trends. Journal of Geology, 99, 1-21.

McLennan, S.M., Hemming, S., McDaniel, D.K. and Hanson, G.N. (1993) Geochemical approaches to sedimentation, provenance and tectonics. In: M. J. Johnsson and A.Basu (Editors), Processes controlling the composition of clastic sediments. Geological Society of America Special Paper, 284, 21-40.

McLennan, S.M., Taylor, S.R. and Hemming, S.R. (2006). Composition, differentiation, and evolution of continental crust: Constraints from sedimentary rocks and heat flow. In: M. Brown and T.Rushmer (Editors), Evolution and Differentiation of the Continental Crust. Cambridge University Press, New York, United States of America, 92-134.

Moore, J.M. (1977). The geology of the Namiesberg, northern Cape. Bulletin of the Precambrian Research Unit, University of Cape Town, South Africa, 20, 69pp.

Moore, J.M. (1989). A comparative study of metamorphosed supracrustal rocks from the western Namaqualand Metamorphic Complex. Bulletin of the Precambrian Research Unit, University of Cape Town, South Africa,
37, 370pp.

Moore, J.M., Watkeys, M.K. and Reid, D.L. (1990). The regional setting of the Aggeneys / Gamsberg base metal deposits, Namaqualand, South Africa. In: P. G. Spry and L. T. Bryndzia (Editors), Regional metamorphism of ore deposits. Science Press, Rotterdam, The Netherlands, 77-95.

Nakamura, N. (1974). Determination of REE, Ba, Fe, Mg, Na and $\mathrm{K}$ in carbonaceous and ordinary chondrites. Geochimica et Cosmochimica Acta, 38, 757-775.

Nesbitt, H.W. and Young, G.M. (1984). Prediction of some weathering trends of plutonic and volcanic rocks based upon thermodynamic and kinetic considerations. Geochimica et Cosmochimica Acta, 48, 1523-1534.

Nesbitt, H.W. and Young, G.M. (1989). Formation and diagenesis of weathering profiles. Journal of Geology, 97, 129-147.

Nicolaysen, L.O. and Burger, A.J. (1965). Note on an extensive zone of 1000 million-year old metamorphic and igneous rocks in southern Africa. Sciences de la Terre, 10, 497-516.

O'Nions, R.K., Hamilton, P.J. and Evensen, N.M. (1977). Variations in ${ }^{143} \mathrm{Nd} /{ }^{144} \mathrm{Nd}$ and ${ }^{87} \mathrm{Sr} /{ }^{86} \mathrm{Sr}$ in oceanic basalts. Earth and Planetary Science Letters, 34, 13-22.

Parr, J.M. and Plimer, I.R. (1993). Models for Broken Hill-type lead-zinc-silver deposits. In: R. V. Kirkham, W. D. Sinclair, R. I. Thorpe and J. M. Duke (Editors), Mineral Deposit Modeling, Geological Association of Canada Special Paper, 40, 253-288.

Pisarevsky, S.A, Wingate, M.T.D., Powell, C.McA., Johnson, S. and Evans, D.A.D. (2003). Models of Rodinia assembly and fragmentation. In: M. Yoshida, B. F. Windley and S. Dasgupta (Editors), Proterozoic East Gondwana: Supercontinent Assembly and Breakup. Geological Society of London Special Publication, 206, 35-55.

Praekelt, H.E. and Schoch, A.E. (1997). Stratigraphical synthesis of the metasediments of the Aggeneys terrane in the Namaqua Mobile Belt. South African Journal of Geology, 100, 85-100.

Praekelt, H.E., Schoch, A.E. and Visser, J.N.J. (1997). The metasediments of the Aggeneys terrane in the Namaqua Mobile Belt: Sedimentary response to extensional-compressional variations in a continental environment. South African Journal of Geology, 100, 101-110.

Raith, J.G., Cornell, D.H., Frimmel, H.E. and De Beer, C.H. (2003). New insights into the geology of the Namaqua Tectonic Province, South Africa, from ion probe dating of detrital and metamorphic zircon. Journal of Geology, 111, 347-366.

Reid, D.L. (1977). Geochemistry of Precambrian igneous rocks in the lower Orange River region. Bulletin of the Precambrian Research Unit, University of Cape Town, South Africa, 23, 397pp.

Reid, D.L. (1979a). Total-rock Rb-Sr and U-Th-Pb isotopic study of Precambrian metavolcanic rocks in the lower Orange River region, southern Africa. Earth and Planetary Science Letters, 42, 368-378.

Reid, D.L. (1979b) Age relationships within the mid-Proterozoic Vioolsdrif batholith, lower Orange River region. Transactions of the Geological Society of South Africa, 82, 305-311.

Reid, D.L. (1982). Age relationships within the Vioolsdrif batholith, lower Orange River region. II. A two-stage emplacement history and the extent of Kibaran overprinting. Transactions of the Geological Society of South Africa, 85, 105-110.

Reid, D.L. (1997). Sm-Nd age and REE geochemistry of Proterozoic arc-related igneous rocks in the Richtersveld Subprovince, Namaqua Mobile Belt, Southern Africa. Journal of African Earth Sciences, 24, 621-633.

Reid, D.L., Welke, H.J., Betton, P.J. and Erlank, A.J. (1987). Composition, age and tectonic setting of amphibolites in the central Bushmanland Group, western Namaqua Province, Southern Africa. Precambrian Research, 36, 99-126.

Reid, D.L., Smith, C.B., Watkeys, M.K., Welke, H.J. and Betton, P.J. (1997a). Whole-rock radiometric age patterns in the Aggeneys-Gamsberg ore district, central Bushmanland, South Africa. South African Journal of Geology, 100, 11-22.

Reid, D.L., Welke, H.J., Smith, C.B. and Moore, J.M. (1997b). Lead isotope patterns in Proterozoic stratiform mineralisation in the Bushmanland Group, Namaqua Province, South Africa. Economic Geology, 92, 248-258. Robb, L.J., Armstrong, R.A. and Waters, D.J. (1999). The history of granulitefacies metamorphism and crustal growth from single zircon U-Pb geochronology: Namaqualand, South Africa. Journal of Petrology, 40, $1747-1770$. 
Rozendaal, A. (1975). The geology of Gamsberg, Namaqualand, South Africa. Unpublished MSc thesis, University of Stellenbosch, Stellenbosch, South Africa. 109pp.

Rozendaal, A. (1978). The Gamsberg zinc deposit, Namaqualand. In: Verwoerd, W.J. (Editor), Mineralisation in metamorphic terrains. Special Publication of the Geological Society of South Africa, 4, 235-265.

Rozendaal, A. (1982). The petrology of the Gamsberg zinc deposit and the Bushmanland iron formations with special reference to their relationships and genesis. Unpublished PhD thesis, University of Stellenbosch, Stellenbosch, South Africa, 349pp.

Rozendaal, A. (1986). The Gamsberg zinc deposit, Namaqualand district. In: C. R. Anhaeusser and S. Maske (Editors), Mineral Deposits of South Africa, Geological Society of South Africa, 1477-1488.

Rozendaal, A. and Stumpfl, E.F. (1984). Mineral chemistry and genesis of Gamsberg zinc deposit, South Africa. Transactions of the Institute of Mining and Metallurgy (Section B: Applied Earth Science), 93, B161-B175.

Ryan, P.J., Lawrence, A.L., Lipson, R.D., Moore, J.M., Paterson, A., Stedman, D.P. and Van Zyl, D. (1986). The Aggeneys base metal sulphide deposits, Namaqualand district. In: C. R. Anhaeusser and S. Maske (Editors) Mineral Deposits of Southern Africa, Special Publication of the Geological Society of South Africa, 1447-1474.

SACS (South African Committee for Stratigraphy) (1980). Stratigraphy of South Africa. Part 1 (Compiler LE Kent), Lithostratigraphy of the Republic of South Africa, South West Africa / Namibia and the Republics of Bophuthatswana, Transkei and Venda. Handbook Geological Survey of South Africa, 8, 690pp.

Stedman, D.P. (1980). The structural geology and metamorphic petrology of Black Mountain, Namaqualand. Unpublished MSc thesis, University of the Witwatersrand, Johannesburg, South Africa. 115pp.

Stumpfl, E.F. (1979). Manganese haloes surrounding metamorphic stratabound base metal deposits. Mineralium Deposita, 14, 207-217.

Taylor, S.R. and McLennan, S.M. (1985). The Continental Crust: Its Composition and Evolution. Blackwell, Oxford, United Kingdom, 312pp.

Taylor, S.R., Rudnick, R.L., McLennan, S.M. and Eriksson, K.A. (1986). Rare earth element patterns in Archean high-grade metasediments and their tectonic significance. Geochimica et Cosmochimica Acta, 50, 2267-2279.

Thomas, R.J., von Veh, M.W. and McCourt, S. (1993a). The tectonic evolution of southern Africa: an overview. Journal of African Earth Sciences, 16, 5-24.

Thomas, R.J., Eglington, B.M. and Bowring, S.A. (1993b). Dating the cessation of Kibaran magmatism in Natal, South Africa. Journal of African Earth Sciences, 16, 247-252.

Thomas, R.J., Eglington, B.M., Bowring, S.A., Retief, E.A. and Walraven, F. (1993c). New isotope data from a Neoproterozoic porphyritic granitoidcharnockite suite from Natal, South Africa. Precambrian Research, 62, 83-101.

Thomas, R.J., Agenbacht, A.L.D., Cornell, D.H. and Moore, J.M. (1994) The Kibaran of southern Africa: tectonic evolution and metallogeny. Ore Geology Reviews, 9, 131-160.

Van Aswegen, G. (1983). The Gladkop Suite - the grey and pink gneisses of Steinkopf. In: Botha, B.J.V. (Editor), The Namaqualand Metamorphic Complex. Special Publication of the Geological Society of South Africa, 10, 31-44.

Van Aswegen, G., Strydom, D., Colliston, W.P., Praekelt, H.E., Schoch, A.E., Blignault, H.J., Botha, B.J.V. and van der Merwe, S.W. (1987). The structural-stratigraphic development of part of the Namaqua metamorphic complex, South Africa: an example of Proterozoic major thrust tectonics. In: A. Kröner (Editor) Proterozoic lithospheric evolution, Geodynamics Series, American Geophysical Union, 17, 207-216.

Walters, S.J. (1996). An overview of Broken Hill Type deposits. In: Pontgratz, J. and Davidson, G. (Editors), New Developments in Broken Hill type deposits. Centre for Ore Deposit and Exploration Studies (CODES) Special Publication 1, University of Tasmania, Hobart, Tasmania, Australia, 1-10. Waters, D.J. (1986). Metamorphic zonation and thermal history of pelitic gneisses from western Namaqualand, South Africa. Transactions of the Geological Society of South Africa, 89, 97-102.

Waters, D.J. (1989). Metamorphic evidence for the heating and cooling of Namaqualand granulites. In: J. S. Daly, R. A. Cliff and B. W. D. Yardley (Editors), Evolution of metamorphic belts. Geological Society Special Publication, 43, 357-363.

Watkeys, M.K. (1986). The Achab gneiss: A 'floor' in Bushmanland or a flaw in Namaqualand? Transactions of the Geological Society of South Africa, 89, 103-116.

Watkeys, M.K., Moore, J.M. and Duncan, A.R. (1988a). Geochemical identification of Mid-Proterozoic felsic pyroclastic: a possible source for Aggeneys base metal mineralisation. Abstract of the International Symposium on Geochemistry and Mineralization in Proterozoic Mobile Belts. Tianjin, China, 109pp.

Watkeys, M.K., Moore, J.M. and Duncan, A.R. (1988b). The pink gneiss of Bushmanland: Mid-Proterozoic felsic pyroclastics. Abstract, Geocongress '88, Geological Society of South Africa, 717-720.

Williams, I.S. (1998). U-Th-Pb geochronology by ion microprobe. In: M. A. McKibben, W. C. Shanks and W. I.Ridley, (Editors), Applications of microanalytical techniques to understanding mineralising processes, Reviews in Economic Geology, 7, 1-35.

Williams, I.S. and Claesson, S. (1987). Isotopic evidence for the Precambrian provenance and Caledonian metamorphism of high grade gneisses from the Seve nappes, Scandinavian Caledonides. II. Ion microprobe zircon U-Th-Pb. Contributions to Mineralogy and Petrology, 97, 205-217.

Willner, A.P. (1995). Pressure-temperature evolution of a low-pressure amphibolite facies terrane in central Bushmanland (Namaqua-Natal Mobile Belt; South Africa). Communications of the geological Survey of Namibia, 10, 5-19.

Willner, A.P., Schreyer, W. and Moore, J.M. (1990). Peraluminous metamorphic rocks from the Namaqualand Metamorphic Complex (South Africa): geochemical evidence for an exhalation-related sedimentary origin in a Mid-Proterozoic rift system. Chemical Geology, 81, 221-240.

Winchester, J.A. and Max, M.D. (1989). Tectonic setting discrimination in clastic sequences: an example from the late Proterozoic Erris Group, Northwest Ireland. Precambrian Research, 45, 191-201.

Wood, D.A., Joron, J.L., Treuil, M., Norry, M. and Tarney, J. (1979). Elemental and $\mathrm{Sr}$ isotope variations in basic lavas from Iceland and the surrounding ocean floor. Contributions to Mineralogy and Petrology, 70, 319-339.

Zindler, A. (1980). Geochemical processes in the Earth's mantle and the nature of crust-mantle interactions: evidence from studies of $\mathrm{Nd}$ and $\mathrm{Sr}$ isotope ratios in mantle-derived igneous rocks and lherzolite nodules. Unpublished PhD thesis, Massachusetts Institute of Technology, Boston, Massachusetts, United States of America. 300pp.

Zindler, A., Hart, S.R., Frey, F.A. and Jakobsson, S.P. (1979). Nd and Sr isotope ratios and rare earth element abundances in Reykjanes Peninsula basalts: evidence for mantle heterogeneity beneath Iceland. Earth and Planetary Science Letters, 45, 249-262.

Editorial handling: J. M. Barton 